\title{
Atık Bitkisel Yağların Çevreye Etkileri ve Geri Dönüşümü Hususunda Halkın Farkındalığının Belirlenmesi: Malatya İli Örneği
}

\author{
Nesrin Dursun ${ }^{1, *}$ \\ ${ }^{1}$ Ardahan Üniversitesi, Mühendislik Fakültesi, Çevre Mühendisliği Bölümü, 75002, Ardahan.

\section{Özet}

Dünyada, hızlı nüfus artışına bağlı olarak çevre kirliliği artmıştır. Çevre kirliliği, toplumun çevre duyarlılığıyla azaltılabilir. Anket uygulamaları ile, halkın duyarlılı̆̆ının olup olmadı̆̆ ve çevresel konulardaki farkındalıkları belirlenebilir. Ayrıca anket değerlendirmeleri, çevre kirliliğini önlemeye yönelik çalışmalar yapan belediyeler, kamu kurumları ve sivil toplum kuruluşlarının çalışmalarına yön vermektedir. Bu çalışma, Malatya ili merkez ilçeleri olan Battalgazi ve Yeşilyurt'ta yaşayan bireylere "atık bitkisel yağların çevreye etkileri ve geri dönüşümü" ile ilgili farkındalıklarını belirlemek amacıyla yapılmıştır. 19 sorudan oluşan anket uygulanarak sonuçları değerlendirilmiştir. Demografik bilgiler, atık bitkisel yağların çevreye etkileri ve geri dönüşümü ile ilgili bilgilerden oluşan ankete her ilçeden 150 birey olmak üzere 300 birey katılmıştır. Çalışma ile evsel atık yağların su, hava ve toprak kirliliğine etkileri ve geri dönüşüme verilmesi (özellikle biyodizel üretiminde ham madde olmast) hususunda halkın ne derece bilinçli olduğu belirlenmiştir. Anket sonrası atık yağların çevreye etkileri hakkında bilgilendirmeler yapılarak, bu etkilerin olmaması ya da asgari seviyelerde olabilmesi için farkındalığı oluşturma hedeflenmiştir. Anket uygulaması sonucunda (i) kızartma tüketiminin katılımcı yaşı ile ters orantılı olduğu; (ii) ankette spesifik sorular olmasına rağmen halkın büyük çoğunluğunun bu spesifik konulara hakim olduğu; (iii) bu farkındalıkta çevre duyarlılıkları başta olmak üzere konu ile ilgili internet, TV, radyo, gazete ve dergileri takip ettikleri; (iv) sivil toplum kuruluşlart ve belediyelerin bilgilendirme faaliyetlerinin etkili olduğu tespit edilmiştir.

\section{$\underline{\text { Anahtar Sözcükler }}$}

Atık Bitkisel Yağ, Çevre Kirliliği, Geri Dönüşüm, Halkın Farkındalı̆̆ı, Anket, Malatya

\section{Identification of Public Awareness on Environmental Effects and Recycling of Waste Vegetable Oils: The Case of Malatya Province}

\begin{abstract}
There has increased in environmental pollution due to rapid population growth in the world. Environmental conscience of society can reduce environmental pollution. Conducting surveys can determine the existence of this conscience and public awareness on environmental issues. In addition, survey results guide the activities of municipalities, public institutions and non-governmental organizations that work to prevent environmental pollution. This study was conducted to determine with individuals living in Battalgazi and Yeşilyurt, which are the central districts of Malatya province, to determine their awareness on "environmental effects and recycling of waste vegetable oils". The results were evaluated by applying a questionnaire consisting of 19 questions. 150 individuals from each district and in total 300 individuals participated in the questionnaire which consisted of information about demography, environmental effects and recycling of waste vegetable oils. The study determined the public awareness on the effects of domestic waste oils on water, air and soil pollution and recycling (especially raw materials in biodiesel production). Following the survey, information has been provided about the effects of waste vegetable oils on the environment by creating awareness to eliminate these effects or minimalize them. Based on the survey results, it has been determined that: (i) frying consumption is inversely proportional to the age of the participants; (ii) even though specific questions were asked, the majority of the population have comprehensive knowledge on these specific issues; (iii) they follow internet, TV, radio, newspapers and magazines related to the subject, especially about the environmental awareness; (iv) informative activities of non-governmental organizations and municipalities are effective.
\end{abstract}

\section{$\underline{\text { Keywords }}$}

Waste Vegetable Oil, Environmental Pollution, Recycling, Public Awareness, Survey, Malatya

\section{Giriş}

Fosil yakıtlar petrol, doğal gaz ve kömür olmak üzere yıllardır en büyük enerji kaynakları olarak rol oynamaktadır. Fosil yakıtların kullanımıyla küresel ısınma, çevresel sorunlar oluşmakta ve yenilenemez olmasından dolayı yakın gelecekte tükenmesi öngörülmektedir (Gui vd. 2008; Endalew vd. 2011). Bu durum, hızlı nüfus artışı ve ekonomik gelişme nedeniyle dünya genelinde artan enerji tüketimiyle kötüleşmiştir. 
Bu nedenle, mevcut fosil yakıtlara alternatif olarak yenilenebilir, çevre dostu, güvenilir ve ekonomik olarak uygulanabilir alternatif enerji kaynakları bulma ihtiyacı ortaya çıkmıştır. Bu bağlamda, yenilenebilir birkaç yakıttan biri olan ve bitkisel yağlardan üretilen biyodizel, dizel motor için petrol türevi dizel yerine potansiyel bir alternatif olarak bildirilmiştir (Gui vd. 2008; Lee vd. 2014). Alternatif yakıtlardan biri olan biyodizel yenilenebilir, toksik olmayan ve biyolojik olarak kolay parçalanabilen bir sıvı yakıt olup dizel motorlarda ayrı ayrı veya konvansiyonel dizel yakıtla karışım halinde kullanılarak son zamanlarda gelecek vadetmektedir. Ayrıca karbonmonoksit, yanmamış hidrokarbonlar, partikül madde ve kükürtdioksit gibi egzoz emisyonlarını azaltmaktadır (Singh ve Singh 2010; Ong vd. 2013; Körbitz 1999; Brito vd. 2007; Chung vd. 2008; OSWER 2004). Biyodizel kullanımı ile (i) hava kalitesi iyileştirilebilir, (ii) sınırlı enerji kaynakları ve ithalata bağımlılık azaltılabilir. Bununla birlikte, konvansiyonel biyodizel üretimi yüksek sermaye ve işletme maliyeti gerektirmektedir (OSWER 2004). Biyodizel; ayçiçek, zeytin, soya, palm, kanola, pamuk, yerfistığı ve keten tohumu gibi bitkisel yağlardan; veya atık yemeklik yağların ham madde olarak kullanılması ile üretilen yenilenebilir bir yakıttır (Parawira 2009; Christopher vd. 2014). Birçok araştırmacı tarafından önerildiği üzere biyodizel üretim maliyeti, mutfak atık yağları gibi düşük maliyetli ham maddeler kullanılarak azaltılabilir (Parawira 2009; Pinto vd. 2005; OSWER 2004). Mutfak atık yağları, kolay bulunabilirliği ve yüksek enerji yoğunluğu nedeniyle önemli ham madde kaynaklarından biri olup alternatif yakıt gereksinimini karşılama potansiyeline sahiptir (Li vd. 2013). Biyodizel üretiminde işlenmemiş bitkisel yağların kullanımına kıyasla, düşük maliyetli olan düşük kalitedeki kızartma yağların kullanımı ham madde yükünü verimli şekilde azaltabilir (Shibasaki-Kitakawa vd. 2011; Li vd. 2009). Yemeklik yüksek sicaklıkta okside olan kullanılmış kızartma yağlarda, kızartma sonrasında gözlenen fiziksel değişimler viskozite artışı, özgül 1sı artışı, yüzey geriliminde değişim, renkte koyulaşma ve köpürme olarak sıralanabilir (Kulkarni ve Dalai 2006).

Atık bitkisel yağlar lavabolara döküldügünde, kanalizasyon sisteminde atıkların tutulmasına ve zamanla boruların daralmasına neden olarak su kirliliğini oluşturmakta dolayısıyla, atık su arıtma tesislerinde ekipmanlara zarar vererek işletim maliyetinde artışa neden olmaktadır. Ayrıca, yüzey sularına ulaşan atık bitkisel yağlar; su yüzeyinde güneş 1şı̆̆ı ve oksijeni engelleyen tabaka oluşturarak alıcı ortama zarar vermekte ve sudaki oksijenin tükenmesini hızlandırarak kuş, balık ve diğer canlı türlerine zarar vermektedir (URL-1 2019). Atık yağlar uygun olmayan şekilde yakıldığında, içeriğindeki ağır metaller atmosfere salınarak hava kirliliğine neden olmaktadır (URL-2 2019). Atık yağlar toprağa döküldüğünde; (i) toprak yapısında bozulma ve verim kaybına dolayısıyla bitkilerin tahribine, (ii) sızma ile yer altı sularına ulaşabilir dolayısıyla yer altı sularının kirlenmesine sebep olabilir. Çöpe dökülen atık yağlar ise, katı atık depolama alanlarında sıklıkla yangın çıkmasına neden olabilir (URL-3 2019).

Bu araştırmada, Malatya ili merkez ilçeleri Battalgazi ve Yeşilyurt’ta yaşayan halkın “Atık Bitkisel Yağların Çevreye Etkileri ve Geri Dönüşümü” hususunda farkındalığının belirlenmesi amaçlanarak anket uygulanmış ve uygulama sonuçları değerlendirilmiştir. Çalışma ile evsel atık yağların su kirliliği, hava kirliliği, toprak kirliliği gibi çevresel etkileri ve geri dönüşüme verilme hususunda halkın ne derece bilinçli olduğu belirlenmiş, anket sonrası atık yağların çevreye etkileri hakkında bilgilendirmeler yapılarak, bu etkilerin olmaması ya da asgari seviyelerde olabilmesi için farkındalığın oluşturulması hedeflenmiştir.

\section{Materyal ve Yöntem}

\section{1. Çalışma Bölgesi}

Çalışmada, bitkisel yağların mutfaklarda kızartma amaçlı kullanımından sonra elde edilen atık yağların, çevreye etkileri ve geri dönüşümü hususunda halkın farkındalığının belirlenmesi amaçlanmıştır. Doğu Anadolu Bölgesi batı tarafında Yukarı Fırat Bölümü'nde bulunan Malatya'nın iki merkez ilçesi Yeşilyurt ve Battalgazi ilçeleri, anket uygulama bölgesi olarak belirlenmiştir. Bu merkez ilçelerde, rastgele seçilen katılımcılara 15 Mayıs-10 Haziran 2019 tarihleri arasında yüz yüze anket uygulanmıştır.

2018 yılı nüfus verilerine göre Malatya nüfusunun \%49.79'unu erkekler, \%50.21'ini kadınlar oluşturmaktadır. Ülkemizde atık yağların toplandığı bölgeler, genellikle merkezi yerleşim bölgeleri olduğundan Malatya'nın iki merkez ilçesi olan Yeşilyurt ve Battalgazi ilçeleri çalışma bölgesi olarak belirlenmiştir. Battalgazi ilçesi Malatya nüfusunun \%37.12'sini, Yeşilyurt ilçesi Malatya nüfusunun \%38.25'ini temsil etmektedir. Battalgazi ilçesi, eski Battalgazi ilçesiyle birlikte Orduzu, Hanımınçiftliği, Beydağı, Yaygın, Erenli beldeleri ve ilden katılan 47 mahalleyi kapsamaktadır (URL-4 2019). Yeşilyurt ilçesi, eski Yeşilyurt ilçesiyle birlikte Yakınca, Gündüzbey, Dilek, Topsöğüt, Şahnahan, Bostanbaş1 beldeleri ve ilden katılan 36 mahalleyi kapsamaktadır (URL-5 2019). Battalgazi ilçe nüfusunun \%32.9’unu 19 ve altı yaş grubu, \%38.7'si 20-44 yaş grubu, \%20.2'si 45-64 yaş grubu, \%8.2'si 65 ve üzeri yaş grubu oluşturmaktadır. Yeşilyurt ilçe nüfusunun \%33.7'sini 19 ve altı yaş grubu, \% 38.9'unu 20-44 yaş grubu, \%20.1'ini 45-64 yaş grubu, \%7.3'ünü 65 ve üzeri yaş grubu oluşturmaktadır. Battalgazi ilçe nüfusunun \%15.1'ini eğitim durumu okur yazar olmayan, okur yazar olup eğitim almamış bireyler, \%46.7'sini ilköğretim, \%24'ünü lise, \%14.2'sini üniversite mezunları ve Yeşilyurt ilçe nüfusunun $\% 14.1$ 'ini eğitim durumu okur yazar olmayan, okur yazar olup eğitim almamış bireyler, \%44'ünü ilköğretim, \%22.1'ini lise, \% 19.8'ini üniversite mezunları kapsamaktadır. Sosyo Ekonomik statülerden A ve B grubu maddi durumu çok yüksek olan bireyleri, C ve D grubu profesyonel meslek sahipleri, yöneticiler, memurlar, küçük iş sahipleri (esnaf), kalifiye işçileri oluşturmaktadır. E grubu ise gelir seviyesi en düşük olan bireylerden oluşmaktadır. 
Yeşilyurt ilçesi, sosyo ekonomik statü durumunda \%48.22'sini A+B grubu, \%51.78'ini C+D grubu temsil etmektedir. Battalgazi ilçesi, sosyo ekonomik statü durumunda \% 42.49'unu A+B grubu, \%57.51'ini C+D grubu temsil etmektedir (URL-6 2019). Her iki ilçede de yaş grubu dağılımı, sosyo ekonomik statü ve eğitim durumunun birbirine yakın oranlarda olduğu belirlenmiştir.

\subsection{Anket Uygulaması}

Anket katılımcılarının Battalgazi ve Yeşilyurt ilçelerinde ikamet ediyor olmasına dikkat edilmiştir. Ayrıca, anket uygulaması yapılırken katılımcıların birbirlerinden etkilenerek cevap verebileceği ön görüldüğünden, tek kişi ile yüz yüze uygulama yapılmasına önem verilmiştir. Uygulama ev, sokak ve park ortamında yapılmıştır. Anket soruları, dört bölüm olarak toplam 19 sorudan oluşmaktadır. Birinci bölüm demografik bilgiler, ikinci bölüm bitkisel kaynaklı yağ kullanım bilgileri, üçüncü bölüm bitkisel kaynaklı yağ atıklarının çevreye etkileri, dördüncü bölüm ise bitkisel kaynaklı yağ atıklarının geri dönüşümü hususunda halkın farkındalığını belirlemeye yönelik sorulardan oluşmaktadır. 18 ve üzeri yaş grubu katılımcıların ağırlıklı tercih edildiği rastgele seçilen gönüllü katılımcılardan Yeşilyurt ilçesinde 150 birey ve Battalgazi ilçesinde 150 birey olmak üzere araştırmaya 300 birey katılmıştır.

\section{Bulgular ve Tartışma}

Anketlerin uygulanması ile elde edilen bulgular aşağıda kapsamlı olarak değerlendirilerek tartışılmıştır.

\subsection{Demografik Bilgiler}

Anket uygulamasının birinci bölümünde, anket katılımcılarının cinsiyeti, medeni durumu, yaşı, eğitim durumu ve ailedeki birey sayısı gibi demografik bilgileri Şekil 1'de verilmiştir. Çalışmaya, Battalgazi katılımcılarının \%48.7'si kadın, \%51.3'ü erkek olmak üzere 150 birey ve Yeşilyurt katılımcılarının \%48'i kadın, \%52'si erkek olmak üzere 150 birey katılmıştır. 18 ve üzeri yaş grubu katılımcıların ağırlıklı tercih edildiği rastgele seçilen katılımcılarla yüz yüze görüşme yapılmıştır. Battalgazi katılımcılarının \%3.3'ü 17 ve altı yaş grubu, \%28.7'si 18-25 yaş grubu, \%25.3'ü 26-35 yaş grubu, \%16's1 36-45 yaş grubu, \%21.3'ü 46-60 yaş grubu, \%5.4'ü 61 ve üzeri yaş grubundan oluşmaktadır. Yeşilyurt katılımcılarının \%4'ü 17 ve altı yaş grubu, \%22'si 18-25 yaş grubu, \%22'si 26-35 yaş grubu, \%21.3'ü 36-45 yaş grubu, $\% 23.3$ 'ü 46-60 yaş grubu, \%7.4'ü 61 ve üzeri yaş grubundan oluşmaktadır. Anket katılımcılarına gelir seviyesi sorusu yöneltilmiş ancak, katılımcıların yarısından fazlası gelir seviyesine cevap vermek istemediği için bu soru değerlendirme dışı bırakılmıştır. Sosyo ekonomik statülere göre ilçelerin maddi durumu değerlendirildiğinde Battalgazi ilçesinde \%42.49 ve Yeşilyurt ilçesinde \% 48.22 oranlarında yüksek gelir seviyesinde bireyler olduğu rapor edilmiştir. Orta gelir seviyesinde bireylerin Battalgazi ilçesinde \%57.51 ve Yeşilyurt ilçesinde \%51.78 oranlarında olduğu bildirilmiştir. Battalgazi ilçe nüfusunun \%8.2'sini 65 ve üzeri yaş grubu, \%20.2'sini 45-64 yaş grubu oluştururken, anket katılımcılarının \%5.4'ünü 61 ve üzeri yaş grubu, \%21.3'ünü 46-60 yaş grubu oluşturmuştur. Yeşilyurt ilçe nüfusunun \%7.3'ünü 65 ve üzeri yaş grubu, \%20.1'ini 45-64 yaş grubu oluştururken, anket katılımcılarının \%7.4'ü 61 ve üzeri yaş grubu, \%23.3'ünü 46-60 yaş grubu oluşturmuştur. Battalgazi ilçe nüfusunun \%70.7'sini ilköğretim-lise, \%14.2'sini üniversite mezunları oluştururken, anket katılımcılarının \%60.7'sini ilköğretim-lise, \%39.3'ünü üniversite mezunları oluşturmuştur. Yeşilyurt ilçe nüfusunun \%66.1'ini ilköğretim-lise, \%19.8'ini üniversite mezunları oluştururken, anket katılımcılarının \%58'ini ilköğretim-lise, \%42'sini üniversite mezunları oluşturmuştur. Ailedeki birey sayısı ile kullanım sonrası oluşan atık yă̆ miktarı arasında doğru orantı olabileceğinden ailedeki birey sayısı sorusu katılımcılara yöneltilmiştir. Ailedeki birey sayısını; Battalgazi katılımcıları \%52'si 3-4, \%25.3'ü 5-7; Yeşilyurt katılımcıları \%44.7'si 3-4, \%41.3'ü 5-7 birey olarak belirtmiştir. 

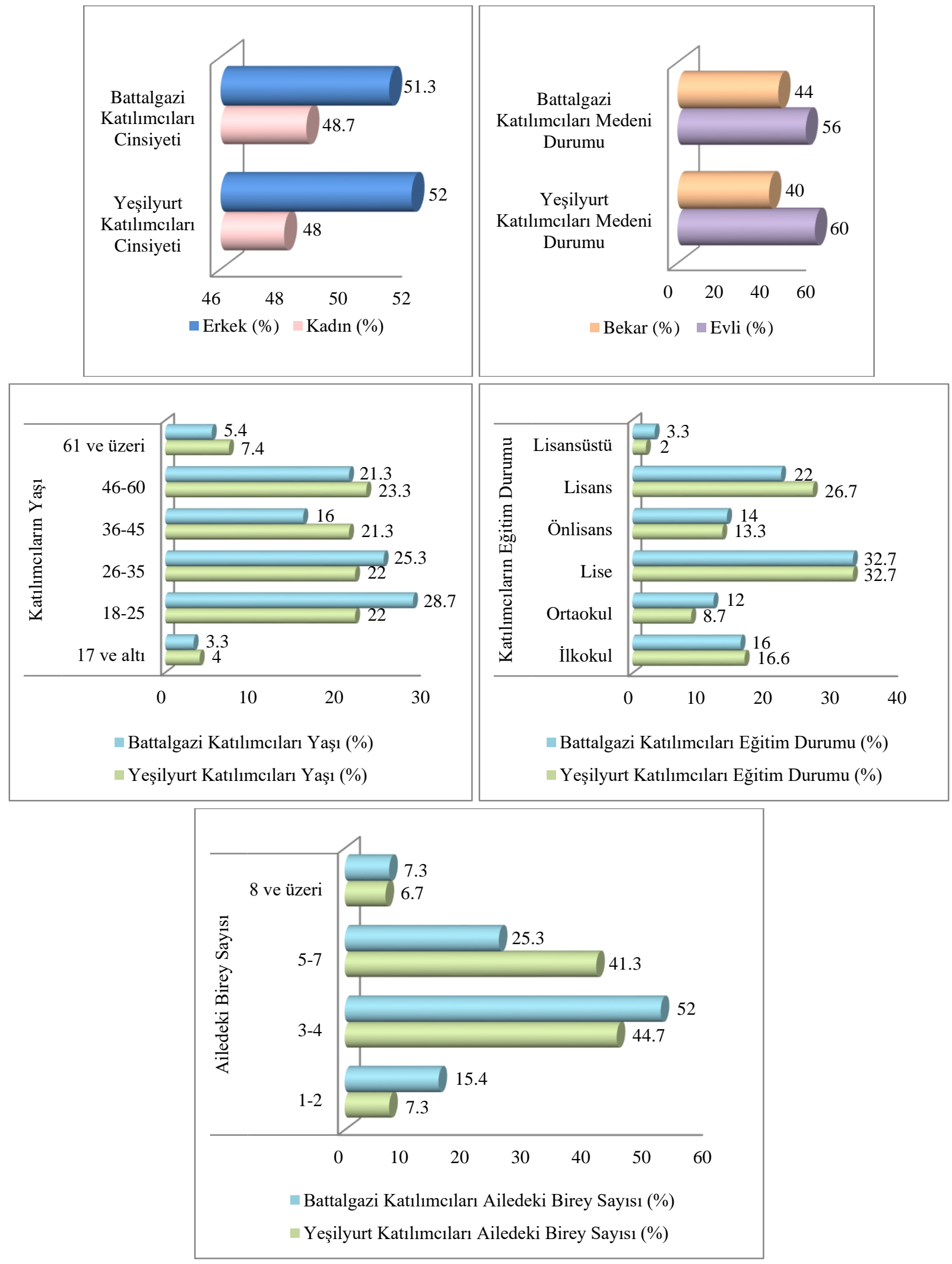

Şekil 1: Katıımcıların demografik bilgileri

\subsection{Bitkisel Kaynaklı Yağ Kullanım Bilgileri}

Malatya'da merkez ilçelerde uygulanmış ankette katılımcılara, "Bitkisel kaynaklı kızartmalık yağ kullanım tercihleri" sorusu yöneltilmiş ve yanıtların oranı Şekil 2'de verilmiştir. 
Battalgazi ilçesinde katılımcıların \%40.2 oran ile aynı oranlarda ayçiçek yağı ve zeytinyağını tercih ettikleri, Yeşilyurt ilçesinde ise katılımcıların \%44.5 oran ile ayçiçek yağını, \%40.5 oran ile zeytinyağını kullanmayı tercih ettikleri belirlenmiştir. Bitkisel Kaynaklı Yağ Kullanım Bilgileri bölümünün ikinci sorusunda katılımcılara "Haftalık kızartma yapma sayısı" sorusu yöneltilmiş ve yanıtların oranı Şekil 3'te verilmiştir. Katılımcıların en yüksek oranda haftalık 1-2 kez kızartma yaptıkları bu oranların Battalgazi ilçesinde \%50.7 oranında, Yeşilyurt ilçesinde \%59.3 oranında olduğu belirlenmiştir. Battalgazi katılımcılarının \%23.3'ü kızartma yapmadıklarını ancak yemek yaparken kullandıkları tüketim sonrası fazla yağı geri dönüşüm için ayırdıklarını, \%16'sı haftalık 3-4 kez kızartma yaptıklarını belirtmiştir. Yeşilyurt katılımcılarının \%21.4'ü haftalık 3-4 kez kızartma yaptıklarını, \%11.3'ü kızartma yapmadıklarını ancak yemek yaparken kullandıkları tüketim sonrası fazla yağı geri dönüşüm için ayırdıklarını Battalgazi katılımcıları gibi belirtmiştir. Her iki ilçede de \%10 civarında haftalık 5 ve üzeri sayıda kızartma yapıldığı belirlenmiştir.

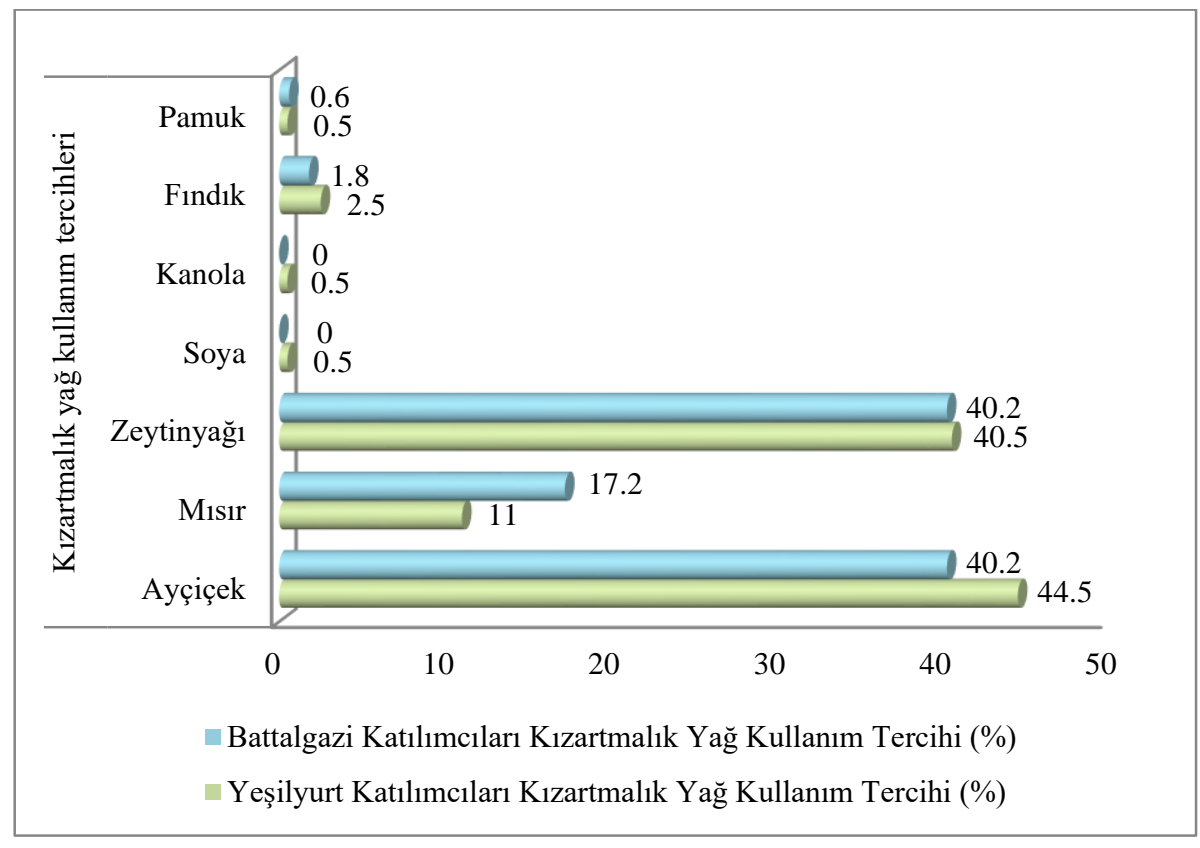

Şekil 2: Katılımcıların kızartmalık yağ kullanım tercihleri

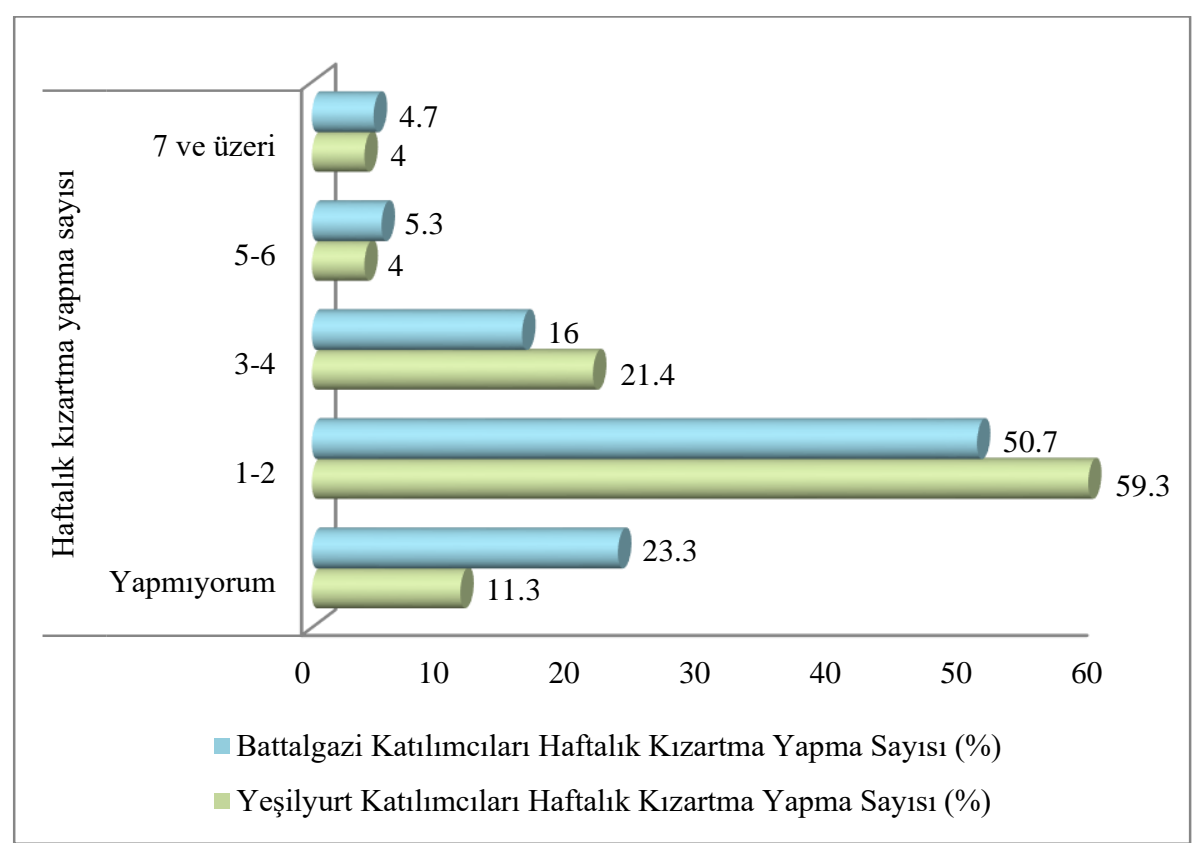

Şekil 3: Katılımcıların haftalık kızartma yapma sayısı 
Bir veya birden fazla seçimin yapılabileceği, yă̆ kullanım tercihlerinin yöneltildiği eğitim durumlarının irdelendiği bu soruya Battalgazi katılımcıları, Ayçiçek yağı kullanımında 12 birey ilkokul, 12 birey ortaokul, 22 birey lise, 9 birey önlisans, 12 birey lisans, 1 birey lisans üstü; Misır yağı kullanımında 11 birey ilkokul, 4 birey ortaokul, 11 birey lise, 1 birey önlisans, 2 birey lisans; Zeytin yağı kullanımında 4 birey ilkokul, 6 birey ortaokul, 20 birey lise, 11 birey önlisans, 22 birey lisans, 4 birey lisans üstü; Kanola yağı kullanımında 1 birey lise; Fındık yağı kullanımında 1 birey ortaokul eğitim durumunda olduğunu beyan etmiştir. Bir veya birden fazla seçimin yapılabileceği, yağ kullanım tercihlerinin yöneltildiği eğitim durumlarının irdelendiği bu soruya Yeşilyurt katılımcıları, Ayçiçek yağı kullanımında 16 birey ilkokul, 8 birey ortaokul, 28 birey lise, 12 birey önlisans, 25 birey lisans, 2 birey lisans üstü; Mısır yağı kullanımında 6 birey ilkokul, 1 birey ortaokul, 10 birey lise, 1 birey önlisans, 4 birey lisans; Zeytin yă̆ı kullanımında 6 birey ilkokul, 6 birey ortaokul, 31 birey lise, 10 birey önlisans, 23 birey lisans, 3 birey lisans üstü; Soya yağı kullanımında 2 birey ilkokul; Fındık yağı kullanımında 1 birey ortaokul, 1 birey lise, 2 birey lisans eğitim durumunda olduğunu beyan etmiştir. Battalgazi katılımcılarının haftalık kızartma yapma sayısının ailedeki birey sayısına göre dağılımı, Yapmıyorum \%5.3 oranında 1-2 birey, \%13.3 oranında 3-4 birey, \%4.7 oranında 5-7 birey; 1-2 kizartma yapma sayısl \%5.3 oranında 1-2 birey, \%30 oranında 3-4 birey, \%11.3 oranında 5-7 birey, \%4 oranında 8 ve üzeri birey; $3-4$ kızartma yapma sayıs $\% 2$ oranında 1-2 birey, \%5.3 oranında 3-4 birey, \%6.7 oranında 5-7 birey, \%2 oranında 8 ve üzeri birey; 5-6 kızartma yapma sayıs $\% 0.7$ oranında 1-2 birey, \%2.7 oranında 3-4 birey, \%2 oranında 5-7 birey; 7 ve üzeri kızartma yapma saylsı \%2 oranında 1-2 birey, \%0.7 oranında 3-4 birey, \%0.7 oranında 5-7 birey, \%1.3 oranında 8 ve üzeri birey olduğu belirlenmiştir. Yeşilyurt katılımcılarının haftalık kızartma yapma sayısının ailedeki birey sayısına göre dağılımı, Yapmiyorum \% 1.3 oranında 1-2 birey, \%8.7 oranında 3-4 birey, \%1.3 oranında 5-7 birey; 1-2 klzartma yapma sayısl \%4 oranında 1-2 birey, \%24.7 oranında 3-4 birey, \%28 oranında 5-7 birey, \%2.7 oranında 8 ve üzeri birey; 3-4 kızartma yapma sayıs $\% 2$ oranında 1-2 birey, $\% 8$ oranında 3-4 birey, \%8 oranında 5-7 birey, $\% 3.3$ oranında 8 ve üzeri birey; 5-6 kızartma yapma sayısı $\% 2$ oranında 3-4 birey, \% 1.3 oranında 5-7 birey, \%0.7 oranında 8 ve üzeri birey; 7 ve üzeri kızartma yapma sayısı \%2.7 oranında 3-4 birey, \%1.3 oranında 5-7 birey olduğu belirlenmiştir.

Bitkisel Kaynaklı Yă̆ Kullanım Bilgileri bölümünün üçüncü sorusunda katılımcılara “Aylık elde etmiş oldukları ortalama atık bitkisel yağ miktarı” sorusu yöneltilmiş ve yanıtların oranı Şekil 4’te verilmiştir. Katılımcıların en yüksek oranda aylık 0.5 kg'den az atık yağ elde ettikleri bu oranların Battalgazi ilçesinde \%48 oranında, Yeşilyurt ilçesinde \%44 oranında olduğu belirlenmiştir. Battalgazi katılımcılarından \%23.4'ü aylık 0.5-1.49 kg arası ortalama atık yă elde ettiklerini, \%13.3'ü aylık 1.5-2.99 kg arası ortalama atık yağ elde ettiklerini beyan etmiştir. Yeşilyurt katılımcılarından \%38.7'si aylık 0.5-1.49 kg arası ortalama atık yağ elde ettiklerini, \%8.6'sı aylık 1.5-2.99 kg arası ortalama atık yağ elde ettiklerini beyan etmiştir.

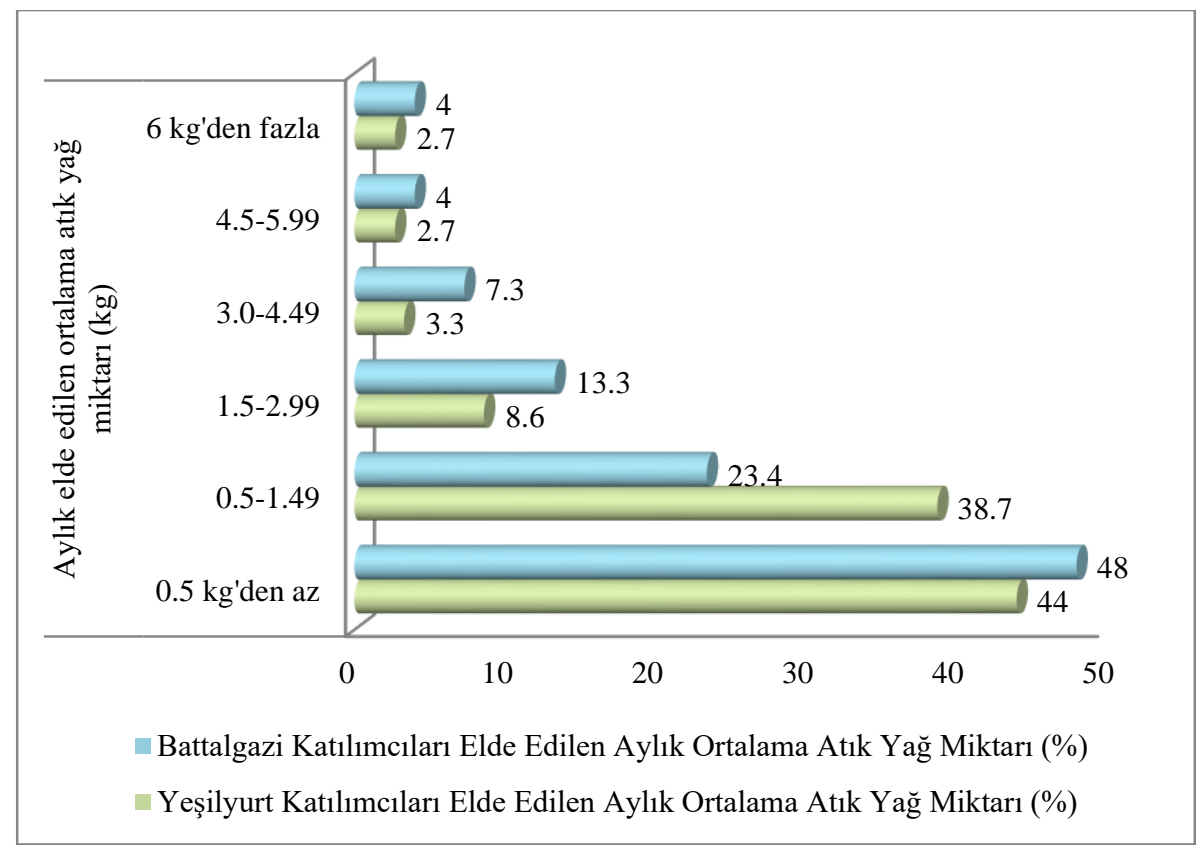

Şekil 4: Katıımcıların aylık elde ettiği ortalama atık yağ miktarı

Battalgazi katılımcılarının elde etmiş oldukları atık yağ miktarlarının ailedeki birey sayısına göre dağılımı, $0.5 \mathrm{~kg}$ 'den az atık yă̆ \% 10 oranında 1-2 birey, \%30 oranında 3-4 birey, \%6 oranında 5-7 birey, \%2 oranında 8 ve üzeri birey; 0.5$1.49 \mathrm{~kg}$ atık yağ \%2.7 oranında 1-2 birey, \%10.7 oranında 3-4 birey, \%8.7 oranında 5-7 birey, \%1.3 oranında 8 ve üzeri birey; $1.5-2.99 \mathrm{~kg}$ atık yă \%2 oranında 1-2 birey, \%6 oranında 3-4 birey, \%4 oranında 5-7 birey, \%1.3 oranında 8 ve üzeri birey; 3.0-4.49 $\mathrm{kg}$ atı $y a \breve{g} \% 0.7$ oranında 1-2 birey, \%2 oranında 3-4 birey, \%3.3 oranında 5-7 birey, \%1.3 oranında 8 ve üzeri birey; 4.5-5.99 $\mathrm{kg}$ atık yăg \%2 oranında 3-4 birey, \%1.3 oranında 5-7 birey, \%0.7 oranında 8 ve üzeri birey; 
$6.0 \mathrm{~kg}$ 'den fazla atık yağ \%1.3 oranında 3-4 birey, \%2 oranında 5-7 birey, \%0.7 oranında 8 ve üzeri birey olduğu belirlenmiştir. Yeşilyurt katılımcılarının elde etmiş oldukları atık yağ miktarlarının ailedeki birey sayısına göre dağılımı, $0.5 \mathrm{~kg}^{\prime}$ den az atı yă̆ \%3.3 oranında 1-2 birey, \%26 oranında 3-4 birey, \%12 oranında 5-7 birey, \%1.3 oranında 8 ve üzeri birey; $0.5-1.49 \mathrm{~kg}$ atı $y a \breve{g} \% 3.3$ oranında 1-2 birey, \%14.7 oranında 3-4 birey, \%20.7 oranında 5-7 birey, \%1.3 oranında 8 ve üzeri birey; $1.5-2.99 \mathrm{~kg}$ atık yağ \%2 oranında 3-4 birey, \%3.3 oranında 5-7 birey, \%3.3 oranında 8 ve üzeri birey; 3.0-4.49 $\mathrm{kg}$ atık yağ \%3.3 oranında 5-7 birey; 4.5-5.99 $\mathrm{kg}$ atık yağ \%0.7 oranında 1-2 birey, \%1.3 oranında 5-7 birey, \%0.7 oranında 8 ve üzeri birey; $6.0 \mathrm{~kg}$ 'den fazla atık yağ \%2 oranında 3-4 birey, \%0.7 oranında 5-7 birey olduğu belirlenmiştir.

\subsection{Bitkisel Kaynaklı Yağ Atıklarının Çevreye Etkileri}

Bu bölümde ilk olarak katılımcılara "1 litre atık bitkisel yağın 1 milyon litre içme suyunu kirletiyor olduğunu biliyor musunuz?” sorusu yöneltilmiş ve yanıtların oranı Şekil 5'te verilmiştir. Su kirliliğine dair spesifik soruda katılımcıların çoğunluğunun Hayır yanıtını vermesi beklenmesine rağmen Battalgazi katılımcıları \%81.3 oranında, Yeşilyurt katılımcıları ise $\% 72$ oranında Evet yanıtını vermiştir.

Battalgazi ilçesi kadın katılımııları, bu soruya \%38 oranında Evet, \%11.4 oranında Hayır yanıtını vermiştir. Battalgazi ilçesi erkek katılımcıları ise, bu soruya \%43.3 oranında Evet, \%7.3 oranında Hayır yanıtını vermiştir. Yeşilyurt ilçesi kadın katılımcıları, bu soruya \%38 oranında Evet, \%10.7 oranında Hayır yanıtını vermiştir. Yeşilyurt ilçesi erkek katılımcıları ise, bu soruya \%33.3 oranında Evet, \%18 oranında Hayır yanıtını vermiştir. Bu soruya Battalgazi ilçesi katılımcılarından, 17 ve altı yaş grubu \% 2 oranında Evet, \%1.3 oranında Hayır; 18-25 yaş grubu \%24.7 oranında Evet, $\% 4$ oranında Hayır; 26-35 yaş grubu \% 22 oranında Evet, \%3.3 oranında Hayır; 36-45 yaş grubu \%10 oranında Evet, \% 6 oranında Hayır; 46-60 yaş grubu \% 18 oranında Evet, \%3.3 oranında Hayır; 61 ve üstü yaş grubu \%4.7 oranında Evet, $\% 0.7$ oranında Hayır yanıtını vermiştir. Bu soruya Yeşilyurt ilçesi katılımcılarından, 17 ve altı yaş grubu \%2.7 oranında Evet, \%1.3 oranında Hayır; 18-25 yaş grubu \%17.3 oranında Evet, \%5.3 oranında Hayır; 26-35 yaş grubu \%14 oranında Evet, \%8 oranında Hayır; 36-45 yaş grubu \%16.7 oranında Evet, \%4 oranında Hayır; 46-60 yaş grubu \%17.4 oranında Evet, \%6 oranında Hayır; 61 ve üstü yaş grubu \%3.3 oranında Evet, \%4 oranında Hayır yanıtını vermiştir. Katılımcıların eğitim durumlarına göre bu soruya Battalgazi ilçesi katılımcılarından, ilkokul mezunları \%13.3 oranında Evet, \%2.7 oranında Hayır; ortaokul mezunları \%7.3 oranında Evet, \%4.7 oranında Hayır; lise mezunları \%24.7 oranında Evet, \%8 oranında Hayır; önlisans mezunları \%13.3 oranında Evet, \%0.7 oranında Hayır; lisans mezunları \%20.7 oranında Evet, \% 1.3 oranında Hayır; lisans üstü mezunları \%2 oranında Evet, \%1.3 oranında Hayır yanıtını vermiştir. Katılımcıların eğitim durumlarına göre bu soruya Yeşilyurt ilçesi katılımcılarından, ilkokul mezunları \%12 oranında Evet, \%4 oranında Hayır; ortaokul mezunları \%3.3 oranında Evet, \%5.4 oranında Hayır; lise mezunları \%23.3 oranında Evet, \%10 oranında Hayır; önlisans mezunları \%11.3 oranında Evet, \%2 oranında Hayır; lisans mezunları \%20 oranında Evet, \%6.7 oranında Hayır; lisans üstü mezunları Hayır yanıtı vermeyerek \%2 oranında Evet yanıtını vermiştir.

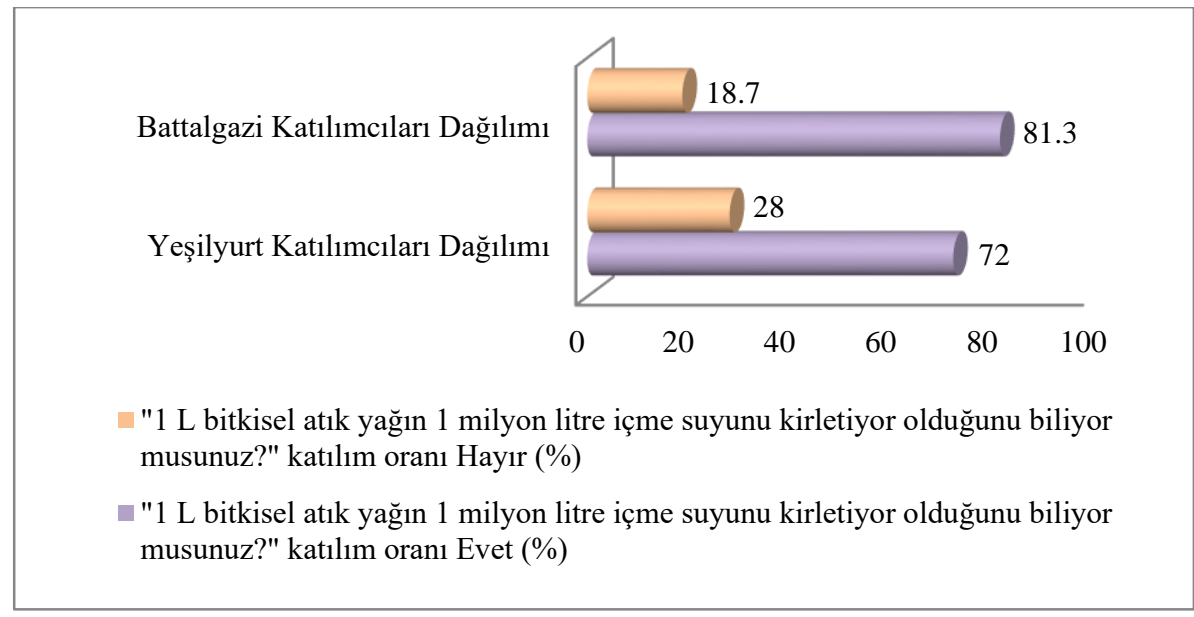

Şekil 5: Katıımcıların "1 litre atık bitkisel yağın 1 milyon litre içme suyunu kirletiyor" olduğunu biliyor musunuz? sorusuna yanıtlarının oranı

Bitkisel Kaynaklı Yağ Atıklarının Çevreye Etkileri bölümünde anket katılımcılarına ikinci olarak "Atık yağlar su kirliliğinin \%25'ini oluşturmaktadır. Bitkisel yağ atıkları lavabolara döküldüğünde, kanalizasyon boruları içinde atıkların tutulmasına ve zamanla borularda daralmalara neden olmaktadır." bilgisine katılım derecesi sorulmuş ve yanıtların oranı Şekil 6'da verilmiştir. Battalgazi katılımcılarının \%42'si kesinlikle katıldı̆̆ını, \%34.7'si katıldığını, \%14'ü ise kararsız olduğunu belirtmiştir. Yeşilyurt katılımcılarının \%55.3'ü kesinlikle katıldığını, \%22'si katıldığını, \%19.3'ü ise kararsız olduğunu belirtmiştir. 


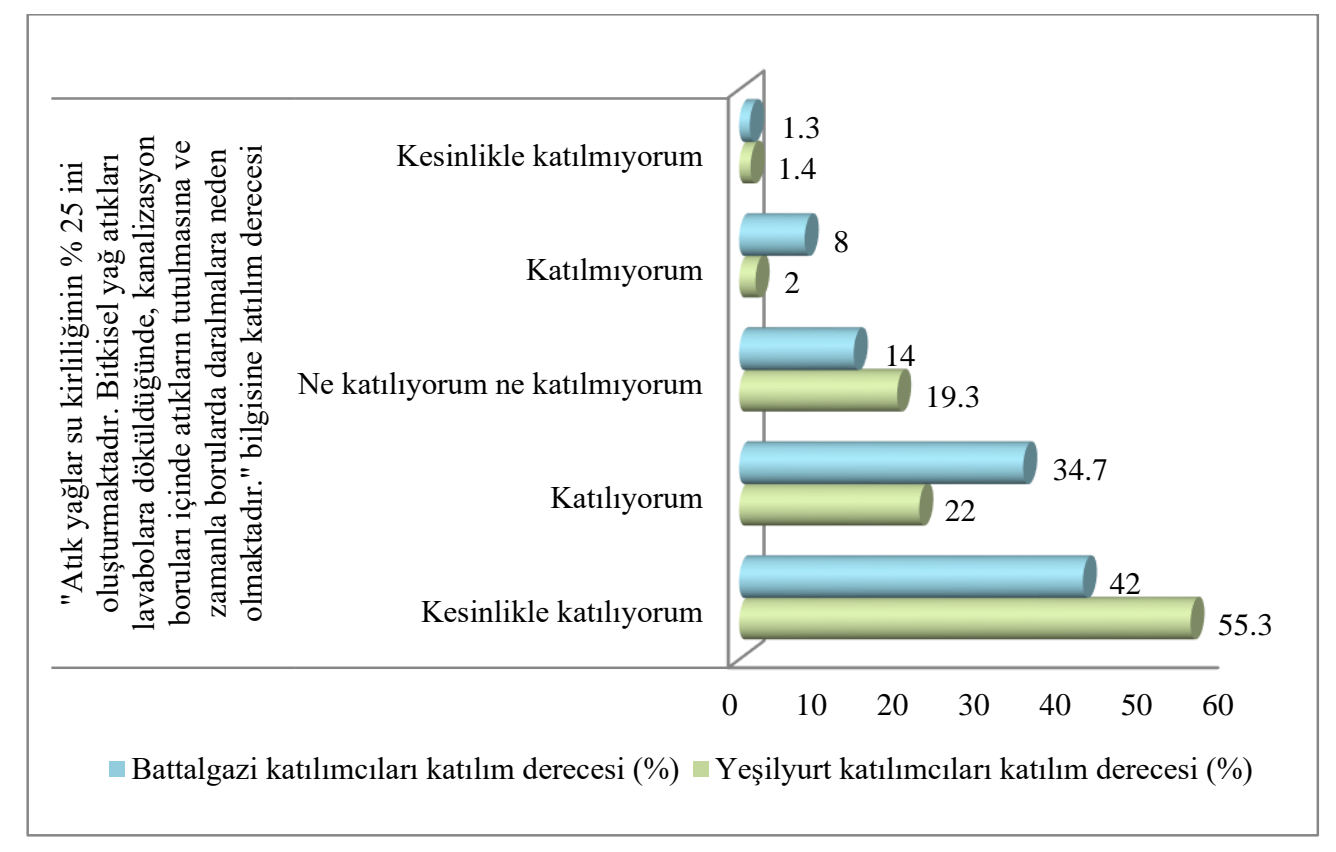

Şekil 6: Katıımcıların atık bitkisel yağların su giderlerine etkileri ile ilgili soruya katıım derecesi

Battalgazi ilçesi kadın katılımcıları, bu soruya \%20 oranında Kesinlikle katılıyorum, $\% 16.7$ oranında Katılıyorum, \%6 oranında Ne katılıyorum ne katılmıyorum, $\% 4.7$ oranında Katılmıyorum, \%1.3 oranında Kesinlikle katılmıyorum yanıtını vermiştir. Battalgazi ilçesi erkek katılımcıları ise, bu soruya \%20.7 oranında Kesinlikle katılıyorum, \%19.3 oranında Katılıyorum, \%8 oranında Ne katılıyorum ne katılmıyorum, \%3.3 oranında Katılmıyorum yanıtını vermiştir. Yeşilyurt ilçesi kadın katılımcıları, bu soruya \%26.7 oranında Kesinlikle katılıyorum, \%11.3 oranında Katılıyorum, \%8 oranında Ne katılıyorum ne katılmıorum, \%1.3 oranında Katılmıyorum, \%0.7 oranında Kesinlikle katılmıyorum yanıtını vermiştir. Yeşilyurt ilçesi erkek katılımcıları ise, bu soruya \%30 oranında Kesinlikle katılıyorum, \%10.6 oranında Katılıyorum, \%10 oranında Ne katılıyorum ne katılmıyorum, \%0.7 oranında Katılmıyorum, \%0.7 oranında Kesinlikle katılmıyorum yanıtını vermiştir. Bu soruya Battalgazi ilçesi katılımcılarından, 17 ve altı yaş grubu $\% 0.7$ oranında Kesinlikle katılıyorum, $\% 1.3$ oranında Katılıyorum, $\% 0.7$ oranında Ne katıliyorum ne katılmıyorum, $\% 0.7$ oranında Katılmıyorum; 18-25 yaş grubu \%14.7 oranında Kesinlikle katılıyorum, \%8.7 oranında Katılıyorum, \%2 oranında Ne katılıyorum ne katılmıyorum, \%2.7 oranında Katılmıyorum, \%0.7 oranında Kesinlikle katılmıyorum; 26-35 yaş grubu $\% 11.3$ oranında Kesinlikle katılıyorum, \%9.3 oranında Katılıyorum, \%2 oranında Ne katılıyorum ne katılmıyorum, \%2 oranında Katılmıyorum, \%0.7 oranında Kesinlikle katılmıyorum; $36-45$ yaş grubu \%5.3 oranında Kesinlikle katılıyorum, $\% 4.6$ oranında Katılıyorum, \% 4 oranında Ne katılıyorum ne katılmıyorum, \%2 oranında Katılmıyorum; 46-60 yaş grubu \%8.7 oranında Kesinlikle katılıyorum, \% 7.3 oranında Katılıyorum, \%5.3 oranında Ne katılıyorum ne katılmıyorum; 61 ve üstü yaş grubu \%1.3 oranında Kesinlikle katılıyorum, \%3.3 oranında Katılıyorum; \%0.7 oranında Katılmıyorum yanıtını vermiştir. Bu soruya Yeşilyurt ilçesi katılımcılarından, 17 ve altı yaş grubu $\% 2$ oranında Kesinlikle katılıyorum, $\% 0.7$ oranında Katılıyorum, \%1.3 oranında Ne katılıyorum ne katılmıyorum; 18-25 yaş grubu \%10.7 oranında Kesinlikle katılıyorum, \%6.6 oranında Katılıyorum, \%4 oranında Ne katılıyorum ne katılmıyorum, \%0.7 oranında Kesinlikle katılmıyorum; 26-35 yaş grubu \%13.3 oranında Kesinlikle katılıyorum, \%3.3 oranında Katılıyorum, $\% 4.7$ oranında Ne katılıyorum ne katılmıyorum, \%0.7 oranında Katılmıyorum; 36-45 yaş grubu \%11.3 oranında Kesinlikle katılıyorum, $\% 6.7$ oranında Katılıyorum, \%2.7 oranında Ne katılıyorum ne katılmıyorum, \%0.7 oranında Kesinlikle katılmıyorum; 46-60 yaş grubu \%16 oranında Kesinlikle katılıyorum, \%3.3 oranında Katılıyorum, $\% 2.7$ oranında Ne katılıyorum ne katılmıyorum, \%1.3 oranında Katılmıyorum; 61 ve üstü yaş grubu $\% 2$ oranında Kesinlikle katılıyorum, \%1.3 oranında Katılıyorum; \%4 oranında Ne katılıyorum ne katılmıyorum yanıtını vermiştir. Katılımcıların eğitim durumlarına göre bu soruya Battalgazi ilçesi katılımcılarından, ilkokul mezunları \%6.7 oranında Kesinlikle katılıyorum, \%5.3 oranında Katıliyorum, \%2 oranında Ne kat1lıyorum ne katılmıyorum, \%2 oranında Katılmıyorum; ortaokul mezunları \%3.3 oranında Kesinlikle katılıyorum, \% 4 oranında Katılıyorum, \%2.7 oranında Ne katıliyorum ne katılmıorum, \%2 oranında Katılmıyorum; lise mezunları \%12 oranında Kesinlikle katılıyorum, \%12 oranında Katılıyorum, \%4.7 oranında $\mathrm{Ne}$ katılıyorum ne katılmıyorum, \%2.7 oranında Katılmıyorum, \%1.3 oranında Kesinlikle katılmıyorum; önlisans mezunları $\% 9.3$ oranında Kesinlikle katılıyorum, \% 4 oranında Katılıyorum, \%0.7 oranında Ne katılıyorum ne katılmıyorum; lisans mezunları \%9.3 oranında Kesinlikle katılıyorum, \%9.3 oranında Katılıyorum, \%2.7 oranında Ne katıllyorum ne katılmıyorum, \%0.7 oranında Katılmıyorum; lisans üstü mezunları $\% 1.3$ oranında Kesinlikle katılıyorum, $\% 1.3$ oranında Ne katılıyorum ne katılmıyorum, \%0.7 oranında Katılmıyorum yanıtını vermiştir. 
Katılımcıların eğitim durumlarına göre bu soruya Yeşilyurt ilçesi katılımcılarından, ilkokul mezunları \%8.7 oranında Kesinlikle katılıyorum, \%3.3 oranında Kat1lıyorum, \%4.7 oranında Ne katılıyorum ne katılmıyorum; ortaokul mezunları $\% 2$ oranında Kesinlikle katılıyorum, \%1.3 oranında Katıliyorum, \%4 oranında Ne katıliyorum ne katılmıyorum, \%2 oranında Katılmıyorum; lise mezunları \%16.7 oranında Kesinlikle katılıyorum, \%9.3 oranında Katılıyorum, \%4.7 oranında Ne katılıyorum ne katılmıyorum, \%1.3 oranında Kesinlikle katılmıyorum; önlisans mezunları \%10 oranında Kesinlikle katılıyorum, \%2 oranında Katılıyorum, \%1.3 oranında Ne katılıyorum ne katılmıyorum; lisans mezunları \%16.7 oranında Kesinlikle katılıyorum, \%4.7 oranında Katılıyorum, \%5.3 oranında Ne katılıyorum ne katılmıyorum; lisans üstü mezunları \%1.3 oranında Kesinlikle katılıyorum, \%0.7 oranında Katılıyorum yanıtını vermiştir.

Anket katılımcılarına üçüncü olarak "Atık yağlar kanalizasyona döküldüğünde, atıksu arıtma tesislerinin ekipmanlarına zarar vererek işletme maliyetinde artışa neden olmaktadır." bilgisine katılım derecesi sorulmuş ve yanıtların oranı Şekil 7'de verilmiştir. Battalgazi katılımcılarının \%40.7'si kesinlikle katıldığını, \%37.3'ü katıldığını, $\% 12.7$ 'si ise kararsız olduğunu bildirmiştir. Yeşilyurt katılımcılarının \%48.7'si kesinlikle katıldığını, \%30.7'si katıldığını, \%16.6'sı ise kararsız olduğunu bildirmiştir.

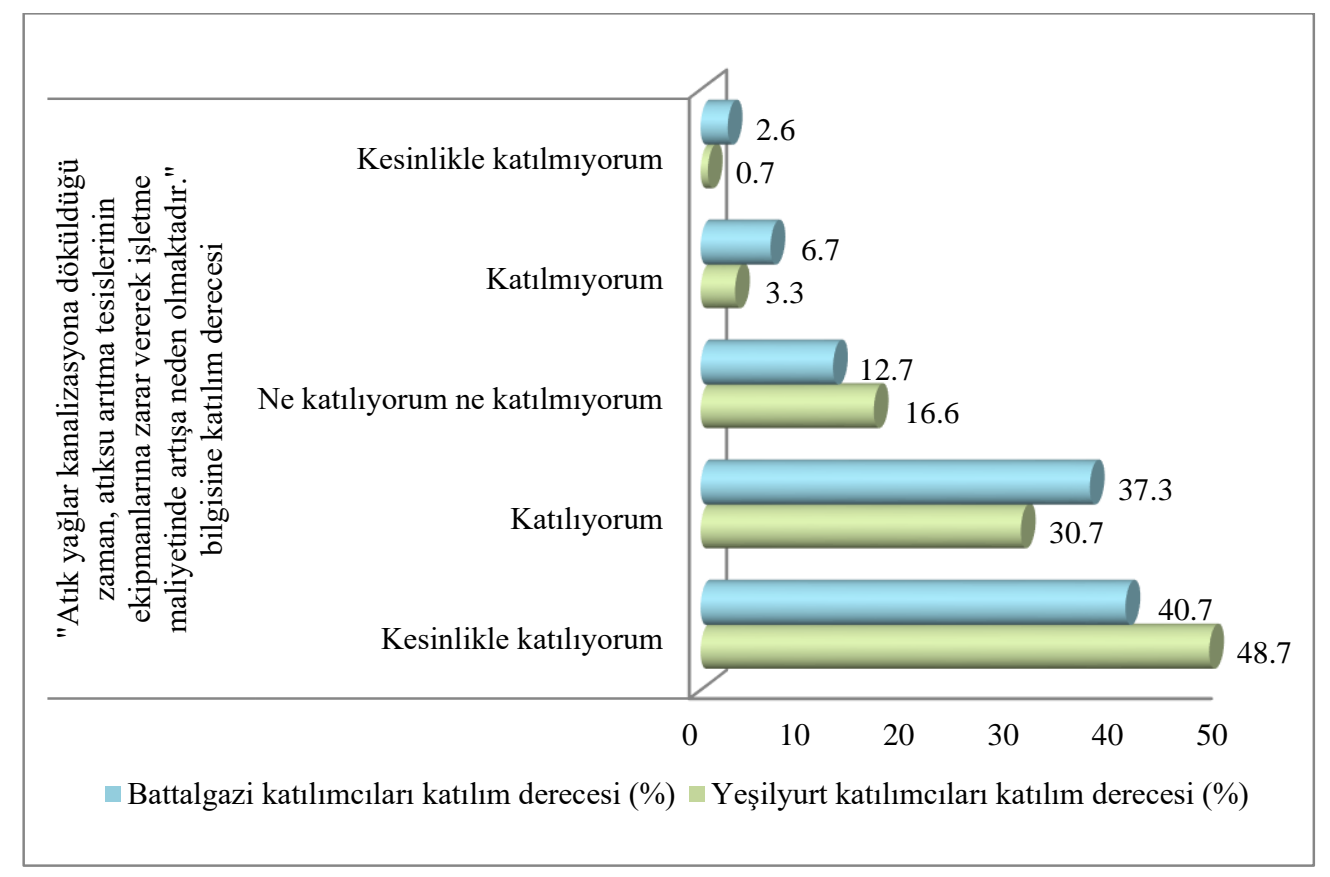

Şekil 7: Katıımcıların atık bitkisel yağların arıtma tesislerine etkileri ile ilgili soruya katılım derecesi

Battalgazi ilçesi kadın katılımcıları, bu soruya \%20 oranında Kesinlikle katılıyorum, \%17.3 oranında Katılıyorum, \%4.7 oranında Ne katıliyorum ne katılmıyorum, \%5.4 oranında Katılmıyorum, \% 1.3 oranında Kesinlikle katılmıyorum yanıtını vermiştir. Battalgazi ilçesi erkek katılımcıları ise, bu soruya \%20.7 oranında Kesinlikle katılıyorum, \%20 oranında Katıliyorum, \%8 oranında Ne katılıyorum ne katılmıyorum, \%1.3 oranında Katılmiyorum, \%1.3 oranında Kesinlikle katılmıyorum yanıtını vermiştir. Yeşilyurt ilçesi kadın katılımcıları, bu soruya \%22 oranında Kesinlikle katıliyorum, \%15.3 oranında Katılıyorum, \%7.4 oranında Ne katılıyorum ne katılmıyorum, \%2 oranında Katılmıyorum, \%0.7 oranında Kesinlikle katılmıyorum yanıtını vermiştir. Yeşilyurt ilçesi erkek katılımcıları ise, bu soruya \%25.3 oranında Kesinlikle katılıyorum, \%16.7 oranında Katılıyorum, \%9.3 oranında Ne katıliyorum ne katılmıyorum, \%1.3 oranında Katılmıyorum yanıtını vermiştir. Bu soruya Battalgazi ilçesi katılımcılarından, 17 ve altı yaş grubu \%1.3 oranında Kesinlikle katıliyorum, \%0.7 oranında Katıliyorum, \%0.7 oranında Ne kat1liyorum ne katılmıorum, \%0.7 oranında Katılmıyorum; 18-25 yaş grubu \%12 oranında Kesinlikle katılıyorum, \%10.6 oranında Katılıyorum, \%2 oranında Ne katılıyorum ne katılmıyorum, \%2 oranında Katılmıyorum, \%2 oranında Kesinlikle katılmıyorum; 26-35 yaş grubu \% 11.3 oranında Kesinlikle katılıyorum, \%10 oranında Katılıyorum, \%2 oranında Ne katıliyorum ne katılmıyorum, $\% 1.3$ oranında Katılmıyorum, \%0.7 oranında Kesinlikle katılmıyorum; 36-45 yaş grubu \%4.7 oranında Kesinlikle katılıyorum, \%6 oranında Katılıyorum, \%3.3 oranında Ne katılıyorum ne katılmıyorum, \%2 oranında Katılmıyorum; 4660 yaş grubu \%9.3 oranında Kesinlikle katılıyorum, \%7.3 oranında Katılıyorum, \%4.7 oranında Ne katılıyorum ne katılmıyorum; 61 ve üstü yaş grubu $\% 2$ oranında Kesinlikle katılıyorum, \%2.7 oranında Katılıyorum, \%0.7 oranında Katılmıyorum yanıtını vermiştir. Bu soruya Yeşilyurt ilçesi katılımcılarından, 17 ve altı yaş grubu \%1.3 oranında Kesinlikle katılıyorum, \%2 oranında Katıliyorum, \%0.7 oranında Ne katılıyorum ne katılmıyorum; 18-25 yaş grubu $\% 11.3$ oranında Kesinlikle katılıyorum, \%6.7 oranında Katılıyorum, \%3.3 oranında Ne katılıyorum ne katılmıyorum, \%0.7 oranında Katılmıyorum; 26-35 yaş grubu \%12 oranında Kesinlikle katılıyorum, \%5.3 oranında Katılıyorum, \%4 oranında Ne katılıyorum ne katılmıyorum, \%0.7 oranında Katılmıyorum; 36-45 yaş grubu \%9.3 oranında Kesinlikle 
katıliyorum, \%8 oranında Katılıyorum, \%2.7 oranında Ne katılıyorum ne katılmıyorum, \%0.7 oranında Katılmıyorum, \%0.7 oranında Kesinlikle katılmıyorum; 46-60 yaş grubu \%13.3 oranında Kesinlikle katılıyorum, \%6.7 oranında Katılıyorum, \%2.7 oranında Ne katılıyorum ne katılmıyorum, \%0.7 oranında Katılmıyorum; 61 ve üstü yaş grubu \%1.3 oranında Kesinlikle katılıyorum, \%2 oranında Katılıorum; \%3.3 oranında Ne katıliyorum ne katılmıorum, \%0.7 oranında Katılmıyorum yanıtını vermiştir. Katılımcıların eğitim durumlarına göre bu soruya Battalgazi ilçesi katılımcılarından, ilkokul mezunları \%5.3 oranında Kesinlikle katılıyorum, \%6.7 oranında Katılıyorum, \%2 oranında Ne katıliyorum ne katılmıyorum, \%1.3 oranında Katılmıyorum, \%0.7 oranında Kesinlikle katılmıyorum; ortaokul mezunları $\% 4$ oranında Kesinlikle katılıyorum, \%2.7 oranında Katıliyorum, \%3.3 oranında Ne katıliyorum ne katılmıorum, \%2 oranında Katılmıyorum; lise mezunları \%12 oranında Kesinlikle katıliyorum, \%11.3 oranında Katılıyorum, \%5.3 oranında Ne katılıyorum ne katılmıyorum, \%2 oranında Katılmıyorum, \%2 oranında Kesinlikle katılmıyorum; önlisans mezunları \%8 oranında Kesinlikle katılıyorum, \%5.3 oranında Katılıyorum, \%0.7 oranında Ne katılıyorum ne katılmıyorum; lisans mezunları \%9.3 oranında Kesinlikle katılıyorum, $\% 11.3$ oranında Katılıyorum, $\% 0.7$ oranında Ne katılıorum ne katılmıyorum, \%0.7 oranında Katılmıyorum; lisans üstü mezunları \%2 oranında Kesinlikle katılıyorum, $\% 0.7$ oranında Ne katılıyorum ne katılmıyorum, \%0.7 oranında Katılmıyorum yanıtını vermiştir. Katılımcıların eğitim durumlarına göre bu soruya Yeşilyurt ilçesi katılımcılarından, ilkokul mezunları \%6.7 oranında Kesinlikle katılıyorum, $\% 5.3$ oranında Kat1liyorum, \%4 oranında Ne katılıyorum ne katılmıyorum, \%0.7 oranında Kesinlikle katılmıyorum; ortaokul mezunları \%1.3 oranında Kesinlikle katılıyorum, \%3.3 oranında Katılıyorum, \%2.7 oranında Ne katılıyorum ne katılmıyorum, \%1.3 oranında Katılmıyorum; lise mezunları \%14 oranında Kesinlikle katılıorum, \%11.3 oranında Katılıyorum, \%5.3 oranında Ne katılıyorum ne katılmıyorum, \%1.3 oranında Katılmıyorum, \%0.7 oranında Kesinlikle katılmıyorum; önlisans mezunları \%10 oranında Kesinlikle katılıyorum, \%2.7 oranında Katılıyorum, \% 0.7 oranında Ne katılıyorum ne katılmıyorum; lisans mezunları \%15.3 oranında Kesinlikle katıliyorum, \%7.3 oranında Katılıorum, \%4 oranında Ne katılıyorum ne katılmıyorum; lisans üstü mezunları \%1.3 oranında Kesinlikle katılıyorum, \%0.7 oranında Katılıyorum yanıtını vermiştir.

Bitkisel Kaynaklı Yağ Atıklarının Çevreye Etkileri bölümünde anket katılımcılarına dördüncü olarak "Deniz, akarsu ve göllere ulaşan atık bitkisel yağlar; su yüzeyinde güneş ışığı ve oksijeni engelleyen tabaka oluşturarak, alıcı ortama zarar vererek ve sudaki oksijenin tükenmesini hızlandırarak kuş, balık ve diğer canlı türlerine zarar vermektedir." bilgisine katılım derecesi sorulmuş ve yanıtların oranı Şekil 8'de verilmiştir. Battalgazi katılımcılarının \%41.3'ü kesinlikle katıldığını, \%36'sı katıldığını, \%12.7'si ise kararsız olduğunu belirtmiştir. Yeşilyurt katılımcılarının \%56'sı kesinlikle katıldığını, \%24.7'si katıldığını, \%17.3'ü ise kararsız olduğunu belirtmiştir.

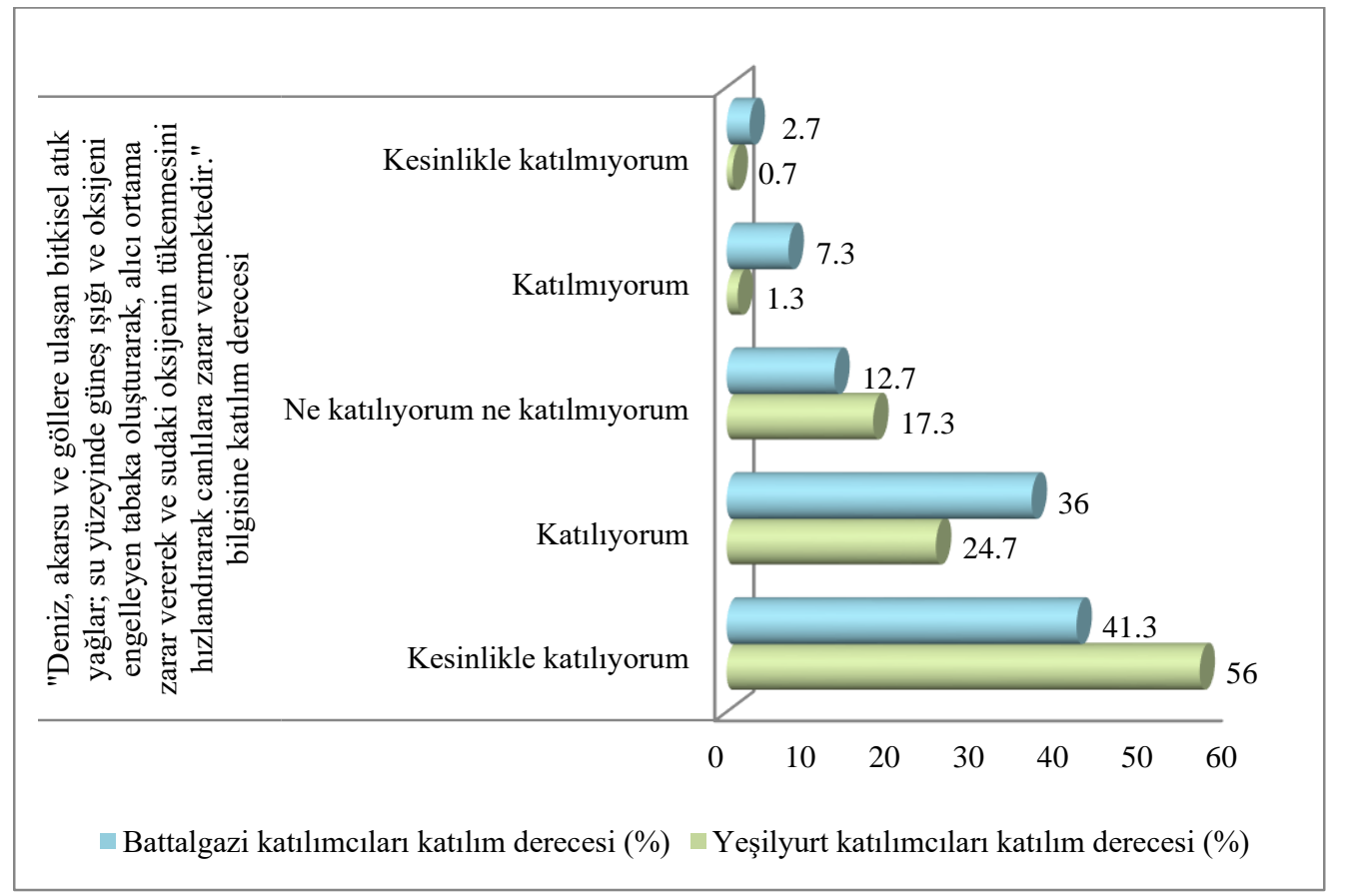

Şekil 8: Katılımcıların atık bitkisel yağların yüzey sularına etkileri ile ilgili soruya katılım derecesi

Battalgazi ilçesi kadın katılımcıları, bu soruya \%19.3 oranında Kesinlikle katılıyorum, \%18.7 oranında Katılıyorum, $\% 6$ oranında Ne katılıyorum ne katılmıyorum, \%4 oranında Katılmıyorum, \%2 oranında Kesinlikle katılmıyorum yanıtını vermiştir. Battalgazi ilçesi erkek katılımcıları ise, bu soruya \%20.7 oranında Kesinlikle katılıyorum, \%17.3 oranında Katılıyorum, \%8 oranında Ne katılıorum ne katılmıyorum, \%3.3 oranında Katılmıyorum, \%0.7 oranında Kesinlikle katılmıyorum yanıtını vermiştir. 
Yeşilyurt ilçesi kadın katılımcıları, bu soruya \%28.6 oranında Kesinlikle katılıyorum, \%10.7 oranında Katılıyorum, \%7.3 oranında Ne katılıyorum ne katılmıyorum, $\% 0.7$ oranında Katılmıyorum, $\% 0.7$ oranında Kesinlikle katılmıyorum yanıtını vermiştir. Yeşilyurt ilçesi erkek katılımcıları ise, bu soruya \%23.3 oranında Kesinlikle katılıyorum, \%14 oranında Katılıyorum, \%14 oranında Ne katılıyorum ne katılmıyorum, \%0.7 oranında Katılmıyorum yanıtını vermiştir. Bu soruya Battalgazi ilçesi katılımcılarından, 17 ve altı yaş grubu \%2 oranında Katılıyorum, \%0.7 oranında Ne katılıyorum ne katılmıyorum, \%0.7 oranında Katılmıyorum; 18-25 yaş grubu \%13.3 oranında Kesinlikle katılıyorum, \%10 oranında Katılıyorum, \%1.3 oranında Ne katılıyorum ne katılmıyorum, \%3.3 oranında Katılmıyorum, \%1.3 oranında Kesinlikle katılmıyorum; 26-35 yaş grubu \%10.7 oranında Kesinlikle katılıyorum, \%10.7 oranında Katılıyorum, \%1.3 oranında Ne katılıorum ne katılmıyorum, \%1.3 oranında Katılmıyorum, \%0.7 oranında Kesinlikle katılmıyorum; 36-45 yaş grubu \%5.3 oranında Kesinlikle katılıyorum, \%5.3 oranında Katıliyorum, \%4 oranında Ne katıliyorum ne katılmıyorum, \%2 oranında Katılmıyorum; 46-60 yaş grubu \%9.3 oranında Kesinlikle katılıyorum, \%6.7 oranında Katılıyorum, \%4.7 oranında Ne katılıyorum ne katılmıyorum; 61 ve üstü yaş grubu \%2 oranında Kesinlikle katılıyorum, \%2.7 oranında Katılıyorum; \%0.7 oranında $\mathrm{Ne}$ katılıyorum ne katılmıyorum yanıtını vermiştir. Bu soruya Yeşilyurt ilçesi katılımcılarından, 17 ve altı yaş grubu \%1.3 oranında Kesinlikle katılıyorum, \%0.7 oranında Katılıyorum, \%2 oranında Ne katılıyorum ne katılmıyorum; 18-25 yaş grubu \%10.7 oranında Kesinlikle katılıyorum, \%7.3 oranında Katılıyorum, \%3.3 oranında $\mathrm{Ne}$ katılıyorum ne katılmıyorum, \%0.7 oranında Katılmıyorum; 26-35 yaş grubu \%15.3 oranında Kesinlikle katıliyorum, $\% 2$ oranında Katılıyorum, \%4.7 oranında Ne katıliyorum ne katılmıyorum, \%0.7 oranında Katılmıyorum; 36-45 yaş grubu \%11.3 oranında Kesinlikle katılıyorum, \%7.3 oranında Katılıyorum, \%2 oranında Ne katılıorum ne katılmıyorum, \%0.7 oranında Kesinlikle katılmıyorum; 46-60 yaş grubu \%13.3 oranında Kesinlikle katılıorum, \%7.3 oranında Katılıyorum, \%2 oranında Ne katılıyorum ne katılmıyorum; 61 ve üstü yaş grubu \%2.7 oranında Kesinlikle katılıyorum, \%1.3 oranında Katılıyorum, \%3.3 oranında Ne katıliyorum ne katılmıyorum yanıtını vermiştir. Katılımcıların eğitim durumlarına göre bu soruya Battalgazi ilçesi katılımcılarından, ilkokul mezunları \%6.7 oranında Kesinlikle katılıyorum, \%5.3 oranında Katılıorum, \%2 oranında Ne katıliyorum ne katılmıyorum, \%1.3 oranında Katılmıyorum, \%0.7 oranında Kesinlikle katılmıyorum; ortaokul mezunları \%4 oranında Kesinlikle katılıyorum, $\% 3.3$ oranında Katılıorum, \%2 oranında Ne katılıyorum ne katılmıyorum, \%2.7 oranında Katılmıyorum; lise mezunları $\% 10.7$ oranında Kesinlikle katılıyorum, \%12 oranında Katılıyorum, \%6 oranında Ne katıliyorum ne katılmıyorum, \%2 oranında Katılmıyorum, \%2 oranında Kesinlikle katılmıyorum; önlisans mezunları \%8 oranında Kesinlikle katılıyorum, \% 5.3 oranında Katılıyorum, \%0.7 oranında Ne katılıyorum ne katılmıyorum; lisans mezunları \% 10 oranında Kesinlikle katılıyorum, \% 10 oranında Katılıyorum, \%1.3 oranında Ne katıliyorum ne katılmıyorum, \%0.7 oranında Katılmıyorum; lisans üstü mezunları \% 1.3 oranında Kesinlikle katılıyorum, \%0.7 oranında Katılıyorum, \%0.7 oranında Ne katılıyorum ne katılmıyorum, \%0.7 oranında Katılmıyorum yanıtını vermiștir. Katılımcıların eğitim durumlarına göre bu soruya Yeşilyurt ilçesi katılımcılarından, ilkokul mezunları \%7.3 oranında Kesinlikle katılıyorum, \% 5.3 oranında Katılıyorum, $\% 4$ oranında Ne katılıyorum ne katılmıyorum; ortaokul mezunları \%3.3 oranında Kesinlikle katılıyorum, \%2 oranında Katılıyorum, \%2.7 oranında Ne katılıyorum ne katılmıyorum, \%0.7 oranında Katılmıyorum; lise mezunları \%17.3 oranında Kesinlikle katılıyorum, \%10 oranında Katılıorum, \%4.7 oranında Ne katılıyorum ne katılmıyorum, \%0.7 oranında Kesinlikle katılmıyorum; önlisans mezunları \%11.3 oranında Kesinlikle katılıorum, \%1.3 oranında Katıliyorum, \%0.7 oranında Ne katılıyorum ne katılmıyorum, \%0.7 oranında Katılmıyorum; lisans mezunları \%15.3 oranında Kesinlikle katılıyorum, \%5.3 oranında Katılıorum, \%5.3 oranında Ne katılıyorum ne katılmıyorum; lisans üstü mezunları \% 1.3 oranında Kesinlikle katılıyorum, \%0.7 oranında Katılıyorum yanıtını vermiştir.

Anket katılımcılarına beşinci olarak "Atık yağlar uygun olmayan şekillerde yakıldığında içindeki ağır metaller atmosfere salınarak hava kirliliğine neden olmaktadır." bilgisine katılım derecesi sorulmuş ve yanıtların oranı Şekil 9'da verilmiştir. Battalgazi katılımcılarının \%42'si kesinlikle katıldığını, \%37.4'ü katıldığını, \%9.3'ü ise kararsız olduğunu bildirmiştir. Yeşilyurt katılımcılarının \%66.7'si kesinlikle katıldığını, \%25.3'ü katıldığını, \%5.3'ü ise kararsız olduğunu bildirmiştir.

Battalgazi ilçesi kadın katılımcıları, bu soruya \%21.3 oranında Kesinlikle katılıyorum, \%19.3 oranında Katılıyorum, $\% 4$ oranında Ne katılıyorum ne katılmıyorum, \%1.3 oranında Katılmıyorum, \%2.7 oranında Kesinlikle katılmıyorum yanıtını vermiştir. Battalgazi ilçesi erkek katılımcıları ise, bu soruya \%22 oranında Kesinlikle katılıyorum, \%16.7 oranında Katılıyorum, \%5.3 oranında Ne katılıyorum ne katılmıyorum, \%4.7 oranında Katılmıyorum, \%2.7 oranında Kesinlikle katılmıyorum yanıtını vermiştir. Yeşilyurt ilçesi kadın katılımcıları, bu soruya \%33.3 oranında Kesinlikle katılıorum, \%10.7 oranında Katıliyorum, \%2.7 oranında Ne katıliyorum ne katılmıyorum, \%0.7 oranında Kesinlikle katılmıyorum yanıtını vermiştir. Yeşilyurt ilçesi erkek katılımcıları ise, bu soruya \% 32.6 oranında Kesinlikle katılıyorum, \%15.3 oranında Katıliyorum, \%2.7 oranında Ne katılıyorum ne katılmıyorum, \%0.7 oranında Katılmıyorum, \%1.3 oranında Kesinlikle katılmıyorum yanıtını vermiştir. Bu soruya Battalgazi ilçesi katılımcılarından, 17 ve altı yaş grubu \%0.7 oranında Kesinlikle katılıyorum, \%2.7 oranında Katılıyorum; 18-25 yaş grubu \%15.3 oranında Kesinlikle katılıyorum, \%8.7 oranında Katılıyorum, \%0.7 oranında Ne katılıyorum ne katılmıyorum, \%2 oranında Katılmıyorum, $\% 2$ oranında Kesinlikle katılmıyorum; 26-35 yaş grubu \%9.3 oranında Kesinlikle katılıyorum, \%12 oranında Katılıyorum, $\% 2$ oranında Ne katılıyorum ne katılmıyorum, \%1.3 oranında Katılmıyorum, \%0.7 oranında Kesinlikle katılmıyorum; 36-45 yaş grubu \%6.7 oranında Kesinlikle katılıyorum, \%4.6 oranında Katılıyorum, \%4 oranında Ne katılıyorum ne katılmıyorum, \%0.7 oranında Katılmıyorum; 46-60 yaş grubu \%8 oranında Kesinlikle katılıorum, \%7.3 oranında Katılıyorum, \%2.7 oranında Ne katılıyorum ne katılmıyorum, \%2 oranında Katılmıyorum, \%1.3 oranında Kesinlikle 
katılmıyorum; 61 ve üstü yaş grubu \%2 oranında Kesinlikle katılıyorum, \%2 oranında Katılıyorum, \%1.3 oranında Kesinlikle katılmıyorum yanıtını vermiştir. Bu soruya Yeşilyurt ilçesi katılımcılarından, 17 ve altı yaş grubu \%2.7 oranında Kesinlikle katılıyorum, \%1.3 oranında Katılıyorum; $18-25$ yaş grubu \%14 oranında Kesinlikle katılıyorum, \%5.3 oranında Katılıyorum, \%1.3 oranında Ne katılıorum ne katılmıyorum, \%1.3 oranında Kesinlikle katılmıyorum; 26-35 yaş grubu \%18 oranında Kesinlikle katılıyorum, \%4 oranında Katılıyorum; 36-45 yaş grubu \%13.3 oranında Kesinlikle katıliyorum, \%6 oranında Katılıorum, \%1.3 oranında Ne katıliyorum ne katılmıyorum, \%0.7 oranında Kesinlikle katılmıyorum; 46-60 yaş grubu \%15.3 oranında Kesinlikle katılıyorum, \%5.3 oranında Katılıyorum, \%2 oranında Ne katılıyorum ne katılmıyorum, \%0.7 oranında Katılmıyorum; 61 ve üstü yaş grubu \%3.4 oranında Kesinlikle katılıyorum, \%3.4 oranında Katılıyorum; \%0.7 oranında Ne katılıyorum ne katılmıyorum yanıtını vermiştir. Katılımcıların eğitim durumlarına göre bu soruya Battalgazi ilçesi katılımcılarından, ilkokul mezunları \%4 oranında Kesinlikle katılıyorum, \%6.7 oranında Katıliyorum, \%1.3 oranında Ne katılıyorum ne katılmıyorum, \%2.7 oranında Katılmıorum, \%1.3 oranında Kesinlikle katılmıyorum; ortaokul mezunları \%4.7 oranında Kesinlikle katılıyorum, \%5.4 oranında Katılıyorum, \%0.7 oranında Ne katılıyorum ne katılmıyorum, \% 1.3 oranında Kesinlikle katılmıyorum; lise mezunları \%13.3 oranında Kesinlikle katılıyorum, \%14 oranında Katılıyorum, \%3.3 oranında Ne katıliyorum ne katılmıyorum, \%0.7 oranında Katılmıyorum, \%1.3 oranında Kesinlikle katılmıyorum; önlisans mezunlar1 \%8.7 oranında Kesinlikle katılıyorum, \%3.3 oranında Katılıorum, \%1.3 oranında Katılmıyorum, \%1.3 oranında Kesinlikle katılmıyorum; lisans mezunları \%8.7 oranında Kesinlikle katılıyorum, \%7.3 oranında Katılıyorum, \%3.3 oranında Ne katıliyorum ne katılmıyorum, \%1.3 oranında Katılmıyorum, \%0.7 oranında Kesinlikle katılmıyorum; lisans üstü mezunları \%2.7 oranında Kesinlikle katılıyorum, \%0.7 oranında Ne katılıyorum ne katılmıyorum yanıtını vermiştir. Katılımcıların eğitim durumlarına göre bu soruya Yeşilyurt ilçesi katılımcılarından, ilkokul mezunları \%9.3 oranında Kesinlikle katılıyorum, \%6.7 oranında Katıliyorum, \% 0.7 oranında Ne katılıyorum ne katılmıyorum; ortaokul mezunları \%4 oranında Kesinlikle katılıyorum, $\% 1.3$ oranında Katılıyorum, \%2.7 oranında Ne katılıyorum ne katılmıyorum, \%0.7 oranında Katılmıyorum; lise mezunları \%22.7 oranında Kesinlikle katılıyorum, \%8.6 oranında Katılıyorum, \%1.3 oranında Kesinlikle katılmıyorum; önlisans mezunları \%12 oranında Kesinlikle katılıyorum, \%1.3 oranında Katılıyorum; lisans mezunlar1 \%17.3 oranında Kesinlikle katıliyorum, \%6.7 oranında Kat1lıyorum, \%2 oranında Ne katıliyorum ne katılmiyorum, \%0.7 oranında Kesinlikle katılmıyorum; lisans üstü mezunları \%1.3 oranında Kesinlikle katılıyorum, \%0.7 oranında Katılıyorum yanıtını vermiştir.

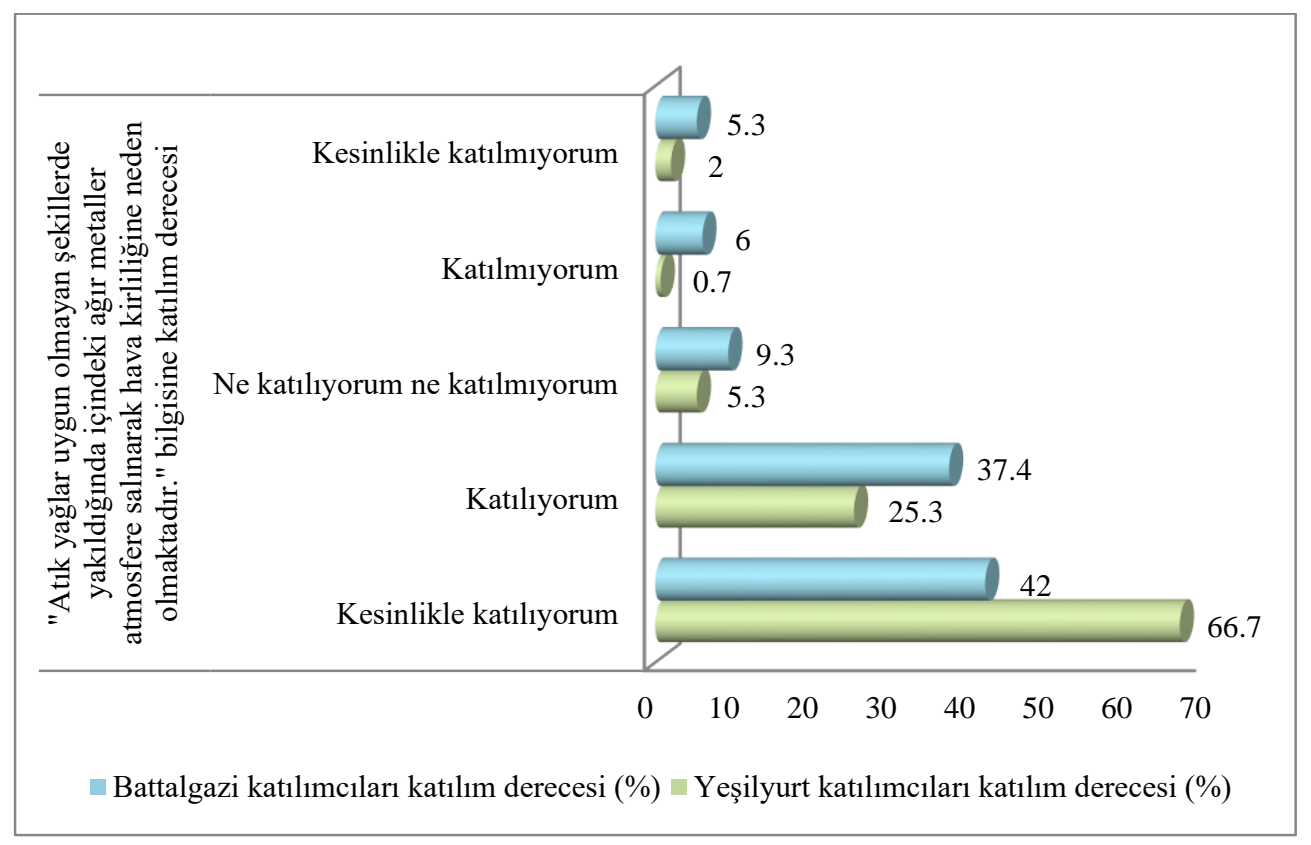

Şekil 9: Katılımcıların atık bitkisel yağların yakılmasının havaya etkileri ile ilgili soruya katılım derecesi

Anket katılımcılarına altıncı olarak "Atık yağlar toprağa döküldüğünde toprak yapısını bozarak verim kaybına neden olur dolayısıyla bitkileri tahrip eder." bilgisine katılım derecesi sorulmuş ve yanıtların oranı Şekil 10’da verilmiştir. Battalgazi katılımcılarının \%51.3'ü kesinlikle katıldığını, \%38.7'si katıldığını, \%8'i ise kararsız olduğunu belirtmiştir. Yeşilyurt katılımcılarının \%62.7'si kesinlikle katıldığını, \%26.7'si katıldığını, \%8'i ise kararsız olduğunu belirtmiştir. Battalgazi ilçesi kadın katılımcıları, bu soruya \%22.7 oranında Kesinlikle katılıyorum, \%21.3 oranında Katılıyorum, \%3.3 oranında Ne katılıyorum ne katılmıyorum, $\% 0.7$ oranında Katılmıyorum, $\% 0.7$ oranında Kesinlikle katılmıyorum yanıtını vermiştir. Battalgazi ilçesi erkek katılımcıları ise, bu soruya \%28.7 oranında Kesinlikle katılıyorum, \%17.3 oranında Katılıyorum, \%4.6 oranında Ne katılıyorum ne katılmıyorum, \%0.7 oranında Kesinlikle katılmıyorum yanıtını vermiştir. Yeşilyurt ilçesi kadın katılımcıları, bu soruya \%30 oranında Kesinlikle katılıyorum, \%14 oranında Katılıyorum, \%2.6 oranında Ne katılıyorum ne katılmıyorum, \%1.3 oranında Kesinlikle katılmıyorum yanıtını vermiştir. 
Yeşilyurt ilçesi erkek katılımcıları ise, bu soruya \%30.7 oranında Kesinlikle katılıyorum, \%12.7 oranında Katılıyorum, \%7.3 oranında Ne katılıyorum ne katılmıyorum, \%0.7 oranında Katılmıyorum, \%0.7 oranında Kesinlikle katılmıyorum yanıtını vermiştir. Bu soruya Battalgazi ilçesi katılımcılarından, 17 ve altı yaş grubu \%0.7 oranında Kesinlikle katılıyorum, \%2.7 oranında Katılıyorum; 18-25 yaş grubu \%18.7 oranında Kesinlikle katılıyorum, \%7.3 oranında Katılıyorum, \%2 oranında Ne katılıyorum ne katılmıyorum, \%0.7 oranında Kesinlikle katılmıyorum; 26-35 yaş grubu \%11.3 oranında Kesinlikle katılıyorum, \%12.7 oranında Katılıyorum, \%1.3 oranında Ne kat1liyorum ne katılmıyorum; 36-45 yaş grubu \%8 oranında Kesinlikle katılıyorum, \% 5.3 oranında Katılıyorum, \%2.7 oranında Ne katılıyorum ne katılmıyorum; 46-60 yaş grubu \%11.3 oranında Kesinlikle katılıyorum, \%7.3 oranında Katılıyorum, \%1.3 oranında Ne katılıyorum ne katılmıyorum, \%0.7 oranında Katılmıyorum, \%0.7 oranında Kesinlikle katılmıyorum; 61 ve üstü yaş grubu $\% 1.3$ oranında Kesinlikle katılıyorum, \%3.3 oranında Katılıyorum, \%0.7 oranında Ne katılıorum ne katılmıyorum yanıtını vermiştir. Bu soruya Yeşilyurt ilçesi katılımcılarından, 17 ve altı yaş grubu \%3.3 oranında Kesinlikle katılıyorum, \%0.7 oranında Katılıyorum; 18-25 yaş grubu \%14 oranında Kesinlikle katılıyorum, \%6 oranında Katılıyorum, \%0.7 oranında Ne katılıyorum ne katılmıyorum, \%1.3 oranında Kesinlikle katılmıyorum; 26-35 yaş grubu \%14.6 oranında Kesinlikle katılıyorum, \%4.7 oranında Katılıyorum, \%2.7 oranında Ne katılıyorum ne katılmıyorum; 36-45 yaş grubu $\% 10$ oranında Kesinlikle katılıyorum, \%8 oranında Katılıyorum, \% 2.7 oranında Ne katılıyorum ne katılmıyorum, \%0.7 oranında Kesinlikle katılmıyorum; 46-60 yaş grubu \% 16.6 oranında Kesinlikle katılıyorum, \%3.3 oranında Katılıyorum, $\% 2.7$ oranında Ne katılıyorum ne katılmıyorum, \%0.7 oranında Katılmıyorum; 61 ve üstü yaş grubu \%2 oranında Kesinlikle katılıyorum, \%4 oranında Katılıyorum, \%1.3 oranında Ne katılıyorum ne katılmıyorum yanıtını vermiştir.

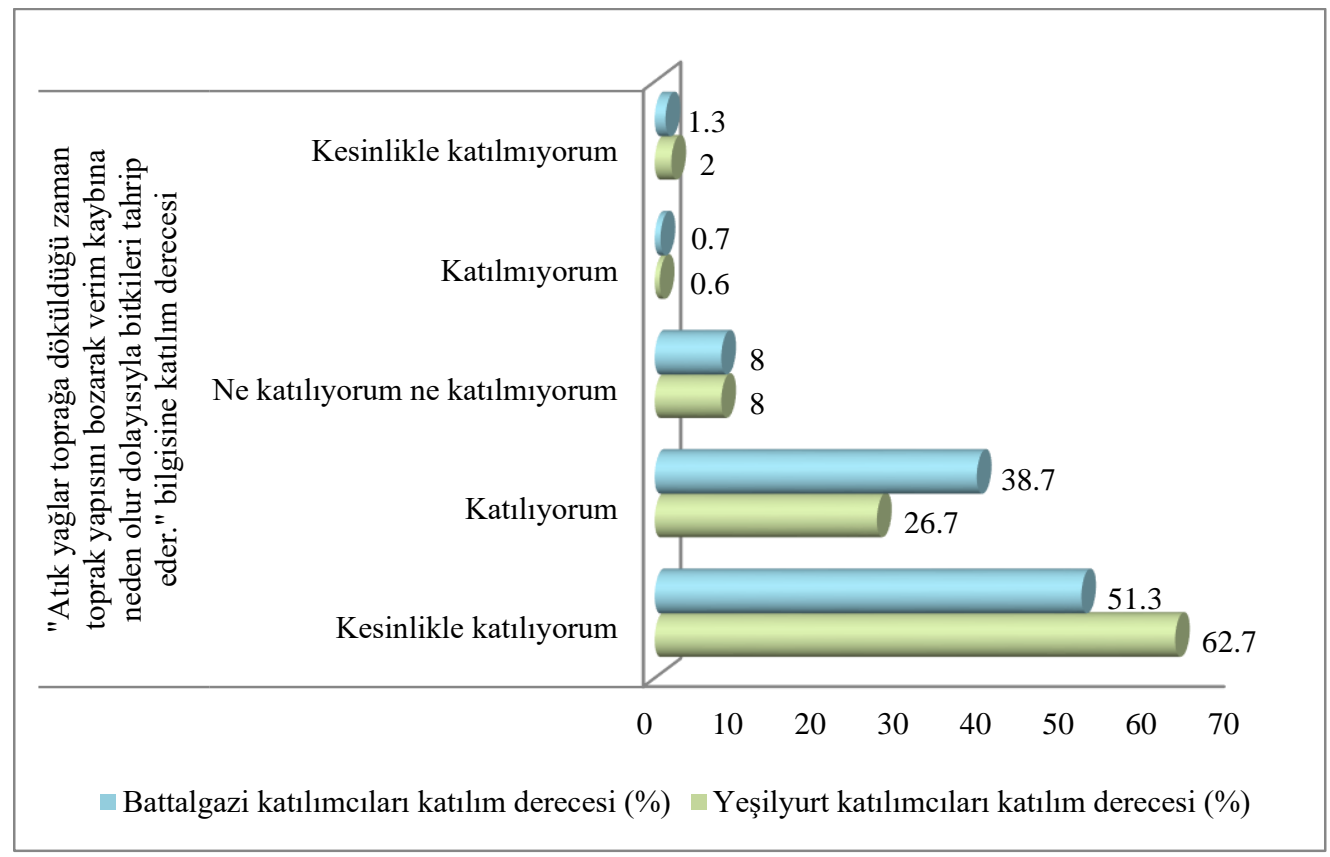

Şekil 10: Katılımcıların atık bitkisel yağların toprağa etkileri ile ilgili soruya katıım derecesi

Katılımcıların eğitim durumlarına göre bu soruya Battalgazi ilçesi katılımcılarından, ilkokul mezunları \%6 oranında Kesinlikle katılıyorum, \%7.3 oranında Katılıorum, \%1.3 oranında Ne katılıyorum ne katılmıyorum, \%0.7 oranında Katılmıyorum, \%0.7 oranında Kesinlikle katılmıyorum; ortaokul mezunları \%4 oranında Kesinlikle katılıyorum, \%6 oranında Katılıyorum, \%1.3 oranında Ne katılıorum ne katılmıyorum, \%0.7 oranında Kesinlikle katılmıyorum; lise mezunları \%18 oranında Kesinlikle katılıyorum, \%12 oranında Katılıyorum, \%2.7 oranında Ne katılıyorum ne katılmıyorum; önlisans mezunları \% 10.7 oranında Kesinlikle katılıyorum, \%3.3 oranında Katılıyorum; lisans mezunları $\% 10$ oranında Kesinlikle katılıyorum, \% 9.3 oranında Katılıyorum, \%2.7 oranında Ne katılıyorum ne katılmıyorum; lisans üstü mezunları \%2.7 oranında Kesinlikle katılıyorum, \%0.7 oranında Katılıyorum yanıtını vermiştir. Katılımcıların eğitim durumlarına göre bu soruya Yeşilyurt ilçesi katılımcılarından, ilkokul mezunları \%7.3 oranında Kesinlikle katılıyorum, $\% 8$ oranında Katılıyorum, \%1.3 oranında Ne katılıyorum ne katılmıyorum; ortaokul mezunları \%3.3 oranında Kesinlikle katıliyorum, \%2.6 oranında Katılıyorum, \%2 oranında Ne katıliyorum ne katılmıyorum, \%0.7 oranında Kesinlikle katılmıyorum; lise mezunları \%20.7 oranında Kesinlikle katılıyorum, \% 9.3 oranında Katılıorum, \%0.7 oranında Ne katıliyorum ne katılmıyorum, \% 0.7 oranında Katılmıyorum, \% 0.7 oranında Kesinlikle katılmıyorum; önlisans mezunları $\% 11.3$ oranında Kesinlikle katılıyorum, \%2 oranında Katılıyorum; lisans mezunları \%18.7 oranında Kesinlikle katıliyorum, \%4 oranında Katılıyorum, \%4 oranında Ne katıliyorum ne katılmıyorum, \%0.7 oranında Kesinlikle katılmıyorum; lisans üstü mezunları \%1.3 oranında Kesinlikle katılıyorum, \%0.7 oranında Katılıyorum yanıtını vermiştir. 
Bitkisel Kaynaklı Yağ Atıklarının Çevreye Etkileri bölümünde anket katılımcılarına yedinci olarak "Toprağa dökülen atık yağlar sızma ile yer altı sularına ulaşabilir. Dolayısıyla, yer altı sularının kirlenmesine neden olur." bilgisine katılım derecesi sorulmuş ve yanıtların oranı Şekil 11'de verilmiştir. Battalgazi katılımcılarının \%52'si kesinlikle katıldığını, \%37.3'ü katıldığını, \%6.7'si ise kararsız olduğunu bildirmiştir. Yeşilyurt katılımcılarının \%60.7'si kesinlikle katıldığını, $\% 27.3$ 'ü katıldığını, \%9.3'ü ise kararsız olduğunu bildirmiştir.

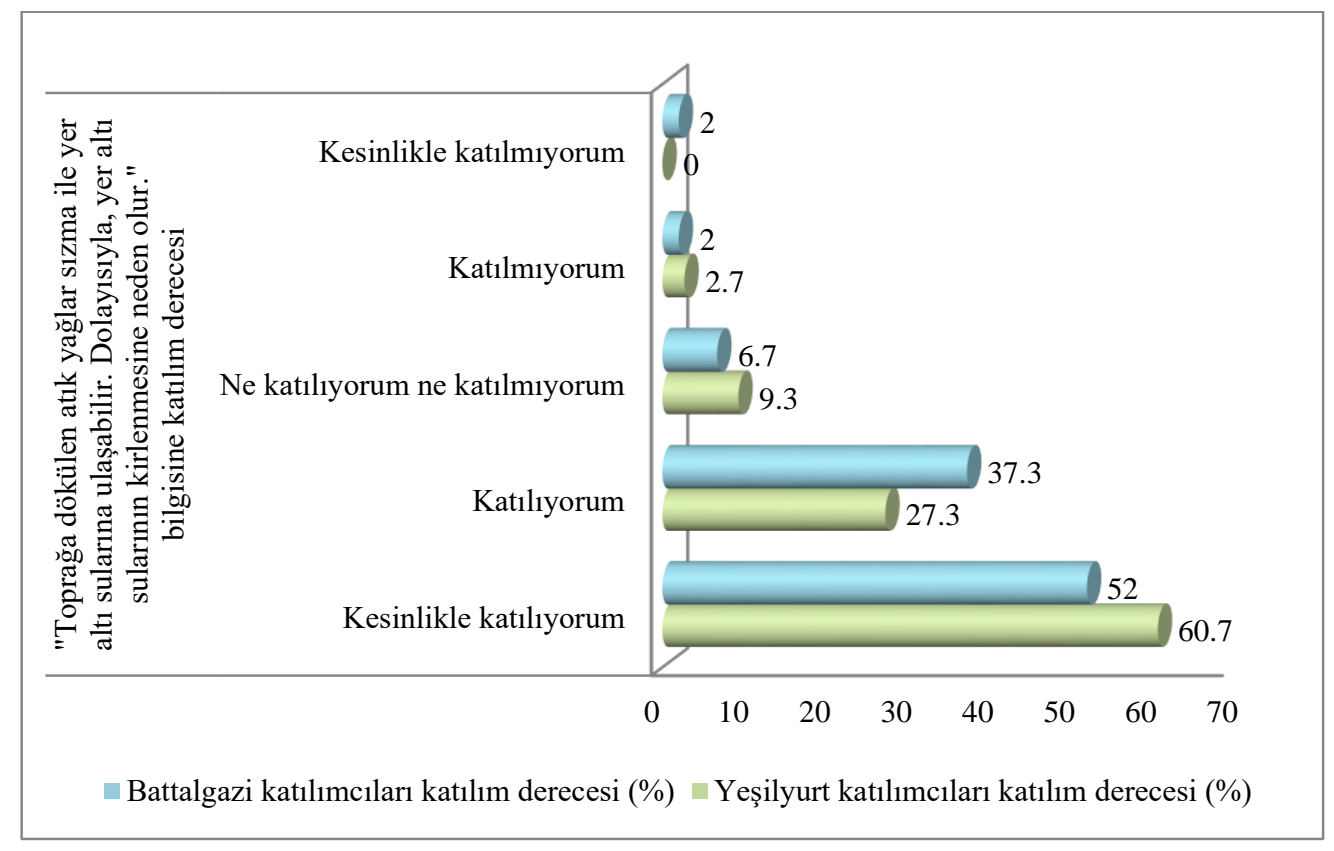

Şekil 11: Katılımcıların atık bitkisel yağların yer altı sularına etkileri ile ilgili soruya katılım derecesi

Battalgazi ilçesi kadın katılımcıları, bu soruya \%24 oranında Kesinlikle katılıyorum, \%20 oranında Katılıyorum, \%2.7 oranında Ne katılıyorum ne katılmıyorum, \% 0.7 oranında Katılmıyorum, \% 1.3 oranında Kesinlikle katılmıyorum yanıtını vermiştir. Battalgazi ilçesi erkek katılımcıları ise, bu soruya \%28 oranında Kesinlikle katılıyorum, \%17.3 oranında Katılıyorum, \%4 oranında Ne katılıorum ne katılmıyorum, \%1.3 oranında Katılmıyorum, \%0.7 oranında Kesinlikle katılmıyorum yanıtını vermiştir. Yeşilyurt ilçesi kadın katılımcıları, bu soruya \%28 oranında Kesinlikle katılıyorum, \%16.7 oranında Katılıyorum, \%3.3 oranında Ne katılıyorum ne katılmıyorum yanıtını vermiştir. Yeşilyurt ilçesi erkek katılımcıları ise, bu soruya \%32.6 oranında Kesinlikle katılıyorum, \%10.7 oranında Katılıorum, \%6 oranında Ne katılıyorum ne katılmıyorum, \%2.7 oranında Katılmıyorum yanıtını vermiştir. Bu soruya Battalgazi ilçesi katılımcılarından, 17 ve altı yaş grubu \%1.3 oranında Kesinlikle katılıyorum, \%2 oranında Katılıyorum; 18-25 yaş grubu $\% 16$ oranında Kesinlikle katılıyorum, \% 8.7 oranında Katılıyorum, \% 2.7 oranında Ne katıliyorum ne katılmıyorum, \%1.3 oranında Kesinlikle katılmıyorum; 26-35 yaş grubu \%12 oranında Kesinlikle katılıyorum, \%11.3 oranında Katılıyorum, $\% 0.7$ oranında Ne katılıyorum ne katılmıyorum, \%1.3 oranında Katılmıyorum; 36-45 yaş grubu \% 9.3 oranında Kesinlikle katılıyorum, \% 6 oranında Katılıyorum, \% 0.7 oranında Ne katılıyorum ne katılmıyorum; 46-60 yaş grubu \%12 oranında Kesinlikle katıliyorum, \%6.6 oranında Katılıyorum, \%2 oranında Ne katılıyorum ne katılmıyorum, \%0.7 oranında Katılmıyorum; 61 ve üstü yaş grubu \% 1.3 oranında Kesinlikle katılıyorum, \% 2.7 oranında Katılıorum, \%0.7 oranında Ne katılıyorum ne katılmıyorum, \% 0.7 oranında Kesinlikle katılmıyorum yanıtını vermiştir. Bu soruya Yeşilyurt ilçesi katılımcılarından, 17 ve altı yaş grubu \% 2.7 oranında Kesinlikle katılıyorum, \% 0.7 oranında Katılıyorum, \% 0.7 oranında Ne katılıyorum ne katılmıyorum; 18-25 yaş grubu \%12.7 oranında Kesinlikle katılıyorum, \% 6 oranında Katılıyorum, \%2.7 oranında Ne katılıyorum ne katılmıyorum, \%0.7 oranında Katılmıyorum; 26-35 yaş grubu \%15.3 oranında Kesinlikle katılıyorum, \% 6.6 oranında Katılıyorum; 36-45 yaş grubu \%11.3 oranında Kesinlikle katılıyorum, \%6.6 oranında Katılıyorum, \% 2.7 oranında Ne katılıyorum ne katılmıyorum, \% 0.7 oranında Katılmıyorum; 46-60 yaş grubu $\% 16$ oranında Kesinlikle katılıyorum, \% 3.3 oranında Katılıyorum, \%2 oranında Ne katılıyorum ne katılmıyorum, \%1.3 oranında Katılmıyorum; 61 ve üstü yaş grubu \%2.7 oranında Kesinlikle katılıyorum, \%4 oranında Katılıyorum; \%1.3 oranında Ne katılıyorum ne katılmıyorum yanıtını vermiştir. Katılımcıların eğitim durumlarına göre bu soruya Battalgazi ilçesi katılımcılarından, ilkokul mezunları \%6 oranında Kesinlikle katılıyorum, \%6 oranında Katılıyorum, \%2 oranında Ne katılıorum ne katılmıyorum, \%1.3 oranında Katılmıyorum, \%0.7 oranında Kesinlikle katılmıyorum; ortaokul mezunları \%8 oranında Kesinlikle katılıyorum, \%3.3 oranında Katılıorum, \%0.7 oranında Ne katılıyorum ne katılmıyorum; lise mezunları \%15.3 oranında Kesinlikle katılıyorum, \%13.3 oranında Katılıorum, \%2.7 oranında Ne katıliyorum ne katılmıyorum, \%1.3 oranında Kesinlikle katılmıyorum; önlisans mezunları \%9.3 oranında Kesinlikle katıliyorum, \%3.3 oranında Kat1liyorum, \%1.3 oranında Ne kat1lıorum ne katılmıyorum; lisans mezunları \%11.3 oranında Kesinlikle katılıyorum, \% 10.7 oranında Katılıyorum, \%0.7 oranında Katılmıyorum; lisans üstü mezunları \%2 
oranında Kesinlikle katılıyorum, \%0.7 oranında Katılıyorum yanıtını vermiştir. Katılımcıların eğitim durumlarına göre bu soruya Yeşilyurt ilçesi katılımcılarından, ilkokul mezunları \%8 oranında Kesinlikle katılıyorum, \%8 oranında Katılıyorum, \% 1.3 oranında Ne katılıyorum ne katılmıyorum; ortaokul mezunları \% 4.7 oranında Kesinlikle katılıyorum, $\% 1.3$ oranında Katılıyorum, \% 2 oranında Ne katılıyorum ne katılmıyorum, \% 0.7 oranında Katılmıyorum; lise mezunları $\% 18$ oranında Kesinlikle katıliyorum, \%10 oranında Katılıyorum, \% 3.3 oranında Ne katılıyorum ne katılmıyorum, \%0.7 oranında Katılmıyorum; önlisans mezunları \%10 oranında Kesinlikle katılıyorum, \%2.7 oranında Katılıyorum, \%0.7 oranında Ne katılıyorum ne katılmıyorum; lisans mezunları \%18 oranında Kesinlikle katılıorum, \%5.3 oranında Katılıyorum, \%2 oranında Ne katılıyorum ne katılmıyorum, \%1.3 oranında Katılmıyorum; lisans üstü mezunları \%1.3 oranında Kesinlikle katılıyorum, \% 0.7 oranında Katılıyorum yanıtını vermiştir.

Bitkisel Kaynaklı Yağ Atıklarının Çevreye Etkileri bölümünde katılımcılara son olarak "Çöpe dökülen atık yağlar çöp depolama alanlarında sık sık yangın çıkmasına neden olmaktadır." bilgisine katılım derecesi sorulmuş ve yanıtların oranı Şekil 12'de verilmiştir. Battalgazi katılımcılarının \% 40.7'si kesinlikle katıldığını, \%39.3'ü katıldığını, \%15.3'ü ise kararsız olduğunu bildirmiştir. Yeşilyurt katılımcılarının \%56'sı kesinlikle katıldığını, \%28.7'si katıldığını, \%10'u ise kararsız olduğunu bildirmiştir.

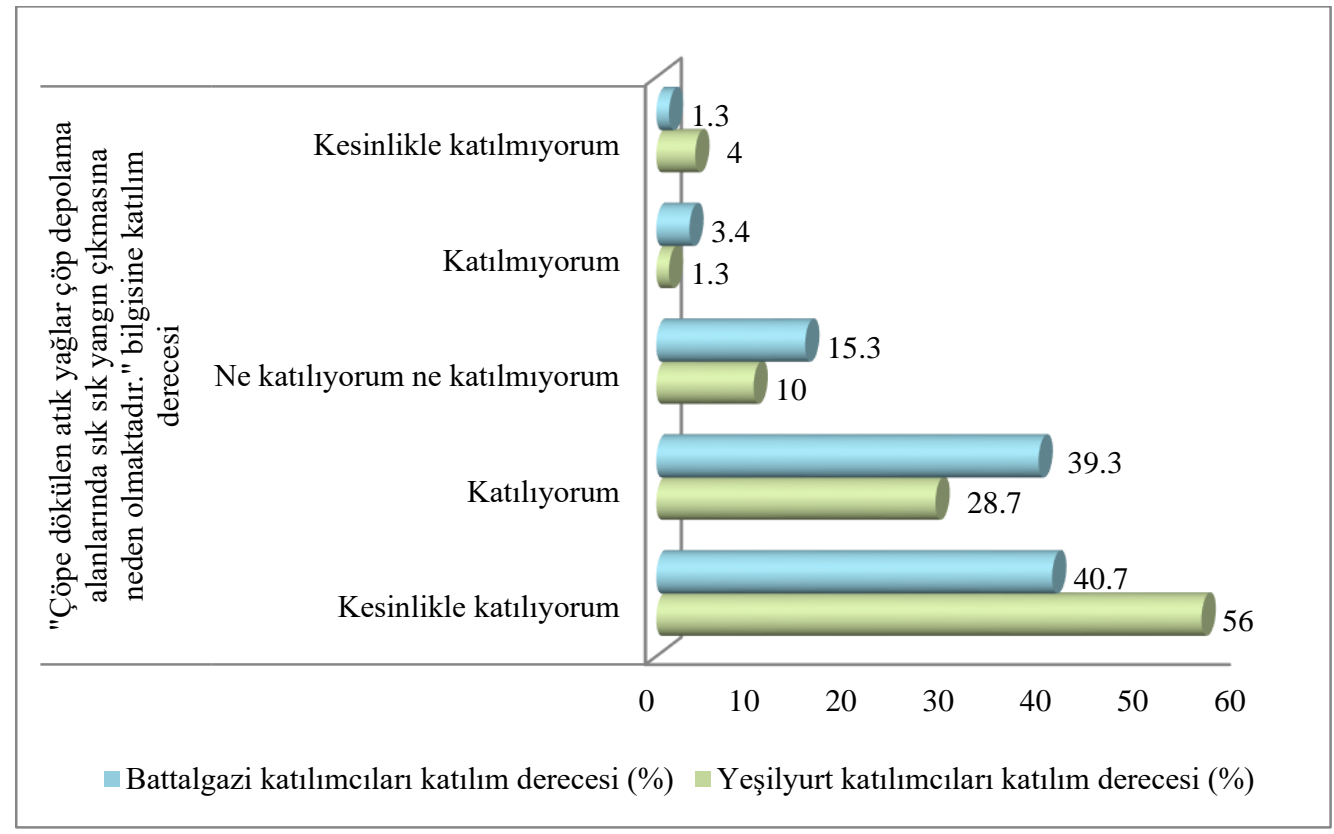

Şekil 12: Katıımcıların atık bitkisel yağların çöpe dökülmesinin etkileri ile ilgili soruya katılım derecesi

Battalgazi ilçesi kadın katılımcıları, bu soruya \%19.3 oranında Kesinlikle katılıyorum, \%19.3 oranında Katılıyorum, \%9.3 oranında Ne katılıyorum ne katılmıyorum, \%0.7 oranında Katılmıyorum yanıtını vermiştir. Battalgazi ilçesi erkek katılımcıları ise, bu soruya \%21.4 oranında Kesinlikle katılıyorum, \%20 oranında Katılıyorum, \%6 oranında Ne katılıyorum ne katılmıyorum, \%2.7 oranında Katılmıyorum, \%1.3 oranında Kesinlikle katılmıyorum yanıtını vermiştir. Yeşilyurt ilçesi kadın katılımcıları, bu soruya \%25.3 oranında Kesinlikle katılıyorum, \%16 oranında Katılıyorum, \%4 oranında Ne katılıyorum ne katılmıyorum, \%2.7 oranında Kesinlikte katılmıyorum yanıtını vermiştir. Yeşilyurt ilçesi erkek katılımcıları ise, bu soruya $\% 30$ oranında Kesinlikle katılıyorum, \% 12 oranında Katılıyorum, \%7.4 oranında Ne katılıyorum ne katılmıyorum, \% 1.3 oranında Katılmıyorum, \% 1.3 oranında Kesinlikle katılmıyorum yanıtını vermiştir. $\mathrm{Bu}$ soruya Battalgazi ilçesi katılımcılarından, 17 ve altı yaş grubu \% 2.7 oranında Katılıyorum, \%0.7 oranında $\mathrm{Ne}$ katılıyorum ne katılmıyorum; 18-25 yaş grubu \%12 oranında Kesinlikle katılıyorum, \%11.3 oranında Katılıyorum, \%4 oranında Ne katıliyorum ne katılmıyorum, \% 0.7 oranında Katılmıyorum \% 0.7 oranında Kesinlikle katılmıyorum; $26-35$ yaş grubu \%10 oranında Kesinlikle katılıorum, \%10.6 oranında Katılıyorum, \%2.7 oranında Ne katılıyorum ne katılmıyorum, \%2 oranında Katılmıyorum; 36-45 yaş grubu \%7.2 oranında Kesinlikle katılıorum, \%4.7 oranında Katılıyorum, \% 4 oranında Ne katılıyorum ne katılmıyorum; 46-60 yaş grubu \%10 oranında Kesinlikle katılıyorum, \%8 oranında Katılıyorum, \%2.7 oranında Ne katılıyorum ne katılmıyorum, \% 0.7 oranında Kesinlikle katılmıyorum; 61 ve üstü yaş grubu \%1.3 oranında Kesinlikle katılıyorum, \% 2 oranında Katılıyorum, \%1.3 oranında Ne katılıyorum ne katılmıyorum, \% 0.7 oranında Kesinlikle katılmıyorum yanıtını vermiştir. Bu soruya Yeşilyurt ilçesi katılımcılarından, 17 ve altı yaş grubu \% 2 oranında Kesinlikle katılıyorum, \% 1.3 oranında Katılıyorum, \% 0.7 oranında Ne katılıyorum ne katılmıyorum; 18-25 yaş grubu \%10 oranında Kesinlikle katılıyorum, \%7.3 oranında Katılıyorum, \%3.4 oranında Ne katılıorum ne katılmıyorum, \%1.3 oranında Kesinlikle katılmıyorum; 26-35 yaş grubu \%13.3 oranında Kesinlikle katılıyorum, \% 5.3 oranında Katılıyorum, \% 1.3 oranında Ne kat1lyorum ne katılmıyorum, \% 0.7 oranında Katılmıyorum, $\% 1.3$ oranında Kesinlikle katılmıyorum; 36-45 yaş grubu \%10 oranında Kesinlikle katılıyorum, \%8 oranında Katılıyorum, 
$\% 2.8$ oranında Ne katılıyorum ne katılmıyorum, \%1.3 oranında Kesinlikle katılmıyorum; $46-60$ yaş grubu \%15.3 oranında Kesinlikle katıliyorum, \%6 oranında Katılıyorum, \%0.7 oranında Ne katılıyorum ne katılmıyorum, \%0.7 oranında Katılmıyorum; 61 ve üstü yaş grubu \%4.7 oranında Kesinlikle katılıyorum, \% 1.3 oranında Katılıyorum, \%1.3 oranında Ne katılıyorum ne katılmıyorum yanıtını vermiştir. Katılımcıların eğitim durumlarına göre bu soruya Battalgazi ilçesi katılımcılarından, ilkokul mezunları \% 4.7 oranında Kesinlikle katılıyorum, \%5.3 oranında Katılıyorum, \%4 oranında Ne katıliyorum ne katılmıyorum, \%2 oranında Katılmıyorum; ortaokul mezunları \% 4.7 oranında Kesinlikle katılıyorum, \%4 oranında Katıliyorum, \%2.7 oranında Ne katılıyorum ne katılmıyorum, \%0.7 oranında Kesinlikle katılmıyorum; lise mezunları \%10.7 oranında Kesinlikle katılıyorum, \%16 oranında Katıliyorum, \%5.3 oranında Ne katılıyorum ne katılmıyorum; önlisans mezunları \%9.3 oranında Kesinlikle katılıyorum, \% 3.3 oranında Katılıyorum, \%0.7 oranında Ne katıliyorum ne katılmıyorum, \%0.7 oranında Kesinlikle katılmıyorum; lisans mezunları \%9.3 oranında Kesinlikle katılıyorum, \% 10.7 oranında Katılıyorum, \%1.3 oranında Ne katılıyorum ne katılmıyorum, \%1.3 oranında Katılmıyorum; lisans üstü mezunları \%3.3 oranında Kesinlikle katılıyorum yanıtını vermiştir. Katılımcıların eğitim durumlarına göre bu soruya Yeşilyurt ilçesi katılımcılarından, ilkokul mezunları \%10 oranında Kesinlikle katılıyorum, \%4.7 oranında Katıliyorum, \% 2 oranında Ne katılıyorum ne katılmıyorum; ortaokul mezunları \% 4 oranında Kesinlikle katılıyorum, $\% 2.7$ oranında Katıliyorum, \%1.3 oranında Ne katılıyorum ne katılmıyorum, \% 0.7 oranında Kesinlikle katılmıyorum; lise mezunları \%18.7 oranında Kesinlikle katılıyorum, \%10 oranında Kat1liyorum, \%1.3 oranında Ne kat1lıyorum ne katılmıyorum, \%0.7 oranında Katılmıyorum, \%2 oranında Kesinlikle katılmıyorum; önlisans mezunları \%8.7 oranında Kesinlikle katıliyorum, \%2.7 oranında Katıliyorum, \%1.3 oranında Ne kat1liyorum ne katılmıyorum, \%0.7 oranında Kesinlikle katılmıyorum; lisans mezunları \%13.3 oranında Kesinlikle katıliyorum, \%8 oranında Katılıorum, \%4 oranında Ne katılıyorum ne katılmıyorum, \% 0.7 oranında Katılmıyorum, \% 0.7 oranında Kesinlikle katılmıyorum; lisans üstü mezunları \% 1.3 oranında Kesinlikle katılıyorum, \% 0.7 oranında Katılıyorum yanıtını vermiştir.

\subsection{Bitkisel Kaynaklı Yağ Atıklarının Geri Dönüşümü}

Bu bölümde ilk olarak katılımcılara "Bitkisel atık yağlar temiz ve ağzı kapaklı ayrı kaplarda toplanarak, toplama işini yapan lisanslı firmalara verilmelidir." sorusu yöneltilmiş ve yanıtların oranı Şekil 13’te verilmiştir. Battalgazi katılımcılarının \%50'si kesinlikle katıldığını, \%34.7'si katıldığını, \%10.7'si ise kararsız olduğunu belirtmiştir. Yeşilyurt katılımcılarının \%64'ü kesinlikle katıldığını, \%27.3'ü katıldığını, \%6.7'si ise kararsız olduğunu belirtmiştir. Battalgazi ilçesi kadın katılımcıları, bu soruya \%24.7 oranında Kesinlikle katılıyorum, \%18 oranında Katılıyorum, \%4 oranında Ne katılıyorum ne katılmıyorum, \%0.7 oranında Katılmıyorum, \%1.3 oranında Kesinlikle katılmıyorum yanıtını vermiştir. Battalgazi ilçesi erkek katılımcıları ise, bu soruya \% 25.3 oranında Kesinlikle katılıyorum, \%16.7 oranında Katılıyorum, \%6.7 oranında Ne katılıyorum ne katılmıyorum, \% 1.3 oranında Katılmıyorum, \%1.3 oranında Kesinlikle katılmıyorum yanıtını vermiştir. Yeşilyurt ilçesi kadın katılımcıları, bu soruya \%32 oranında Kesinlikle katılıyorum, \%14.6 oranında Katılıyorum, \%2.7 oranında Ne katılıyorum ne katılmıyorum, \%1.3 oranında Katılmıyorum yanıtını vermiştir. Yeşilyurt ilçesi erkek katılımcıları ise, bu soruya \%32 oranında Kesinlikle katılıyorum, \%12.7 oranında Katılıyorum, \% 4 oranında Ne katılıyorum ne katılmıyorum, \%0.7 oranında Kesinlikle katılmıyorum yanıtını vermiştir. Katılımcıların eğitim durumlarına göre bu soruya Battalgazi ilçesi katılımcılarından, ilkokul mezunları \%5.3 oranında Kesinlikle katılıyorum, \%7.3 oranında Katıliyorum, \%2.7 oranında Ne katıliyorum ne katılmıyorum, \%0.7 oranında Kesinlikle katılmıyorum; ortaokul mezunları \% 6.7 oranında Kesinlikle katılıyorum, \% 3.3 oranında Kat1liyorum, \%0.7 oranında Ne katılıorum ne katılmıyorum, \%1.3 oranında Kesinlikle katılmıyorum; lise mezunları \%16.7 oranında Kesinlikle katıliyorum, \%12 oranında Katılıyorum, \%3.3 oranında Ne katılıyorum ne katılmıyorum, \% 0.7 oranında Katılmıyorum; önlisans mezunları $\% 10$ oranında Kesinlikle katılıyorum, \% 2.7 oranında Katılıyorum, \% 0.7 oranında Ne katıliyorum ne katılmıyorum, \%0.7 oranında Kesinlikle katılmıyorum; lisans mezunları \%8 oranında Kesinlikle katılıyorum, \%9.3 oranında Katılıyorum, \%3.3 oranında Ne katılıyorum ne katılmıyorum, \%1.3 oranında Katılmıyorum; lisans üstü mezunları \%3.3 oranında Kesinlikle katılıyorum yanıtını vermiştir. Katılımcıların eğitim durumlarına göre bu soruya Yeşilyurt ilçesi katılımcılarından, ilkokul mezunları \%10 oranında Kesinlikle katılıyorum, \%6 oranında Katılıyorum, \%1.3 oranında Ne katılıyorum ne katılmıyorum; ortaokul mezunları \%4.6 oranında Kesinlikle kat1liyorum, \% 1.3 oranında Kat1lıyorum, $\% 2$ oranında Ne katılıyorum ne katılmıyorum, \%0.7 oranında Katılmıyorum; lise mezunları \%20.7 oranında Kesinlikle katıliyorum, \% 10.6 oranında Katılıorum, \%0.7 oranında Ne katılıyorum ne katılmıyorum, \% 0.7 oranında Katılmıyorum; önlisans mezunları \%8 oranında Kesinlikle katılıyorum, \%4 oranında Katıliyorum, \%0.7 oranında Kesinlikle katılmıyorum; lisans mezunları \%20 oranında Kesinlikle katılıyorum, \%4.7 oranında Katıliyorum, \%2 oranında Ne katılıyorum ne katılmıyorum; lisans üstü mezunları \%1.3 oranında Kesinlikle katılıyorum, \%0.7 oranında Katılıyorum yanıtını vermiştir. 


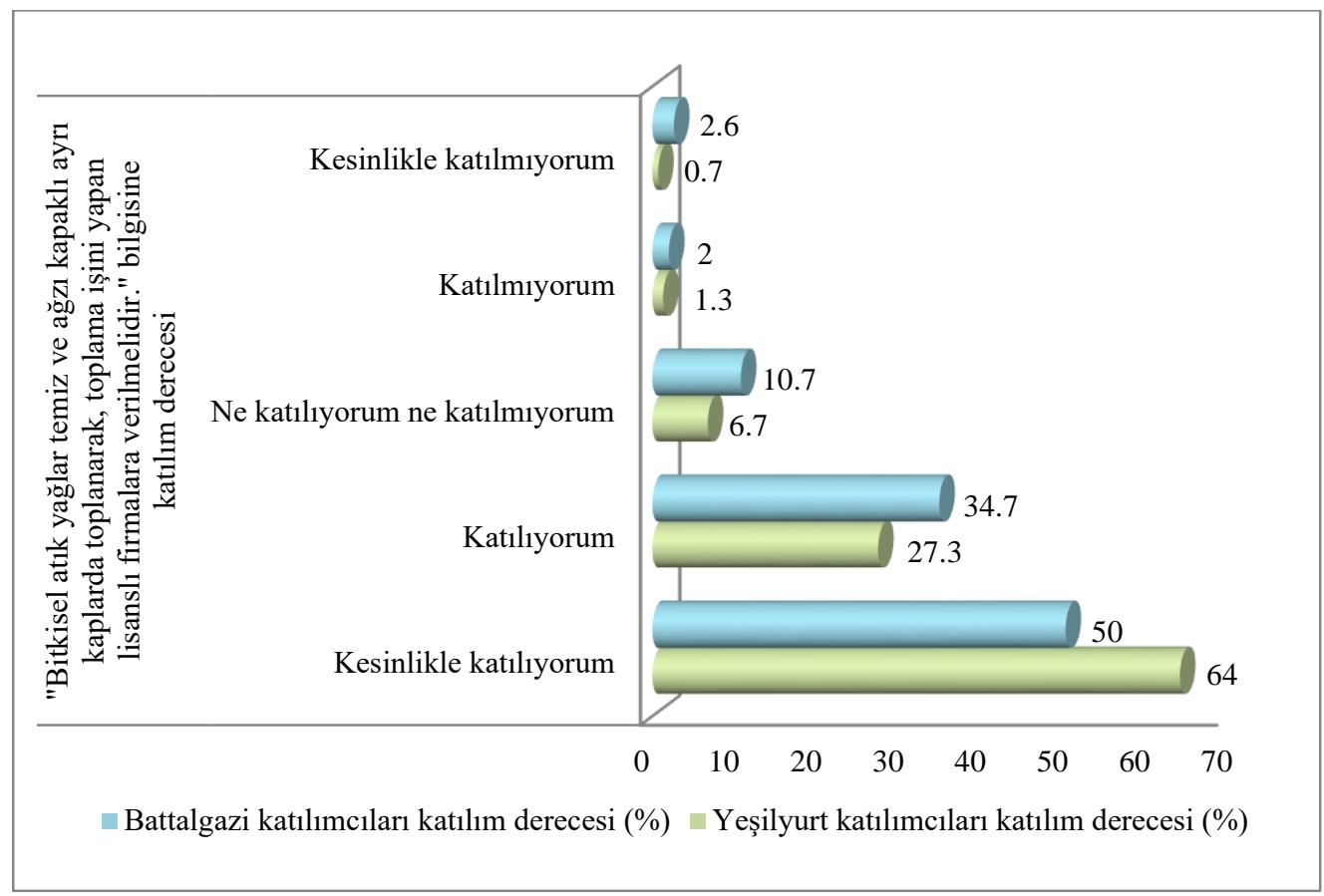

Şekil 13: Katılımcıların bitkisel atık yağların lisanslı firmalara verilmeli bilgisine katılım derecesi

Bitkisel Kaynaklı Yağ Atıklarının Geri Dönüşümü bölümünde anket katılımcılarına ikinci olarak "Geri dönüşüm ve yeniden kazanım işleminde kullanılmak üzere toplanan atık yağlar aşağıdaki üretim alanlarının hangisi yada hangilerinde kullanılmaktadır?" sorusu yöneltilmiş ve yanıtların oranı Şekil 14'te verilmiştir. Battalgazi katılımcılarının \%13.4'ü Biyodizel, \%10.9'u Sabun, \%14.4'ü Hayvan yemi, \%16.3'ü Kimya sanayi, \%17.3'ü Elektrik üretimi, \%27.7'si ise Hepsi olarak beyanda bulunmuştur. Yeşilyurt katılımcılarının \%32.2'si Biyodizel, \%9.9'u Sabun, \%6.9'u Hayvan yemi, \%18.3'ü Kimya sanayi, \%8.9'u Elektrik üretimi, \%23.8'i Hepsi olarak beyanda bulunmuştur.

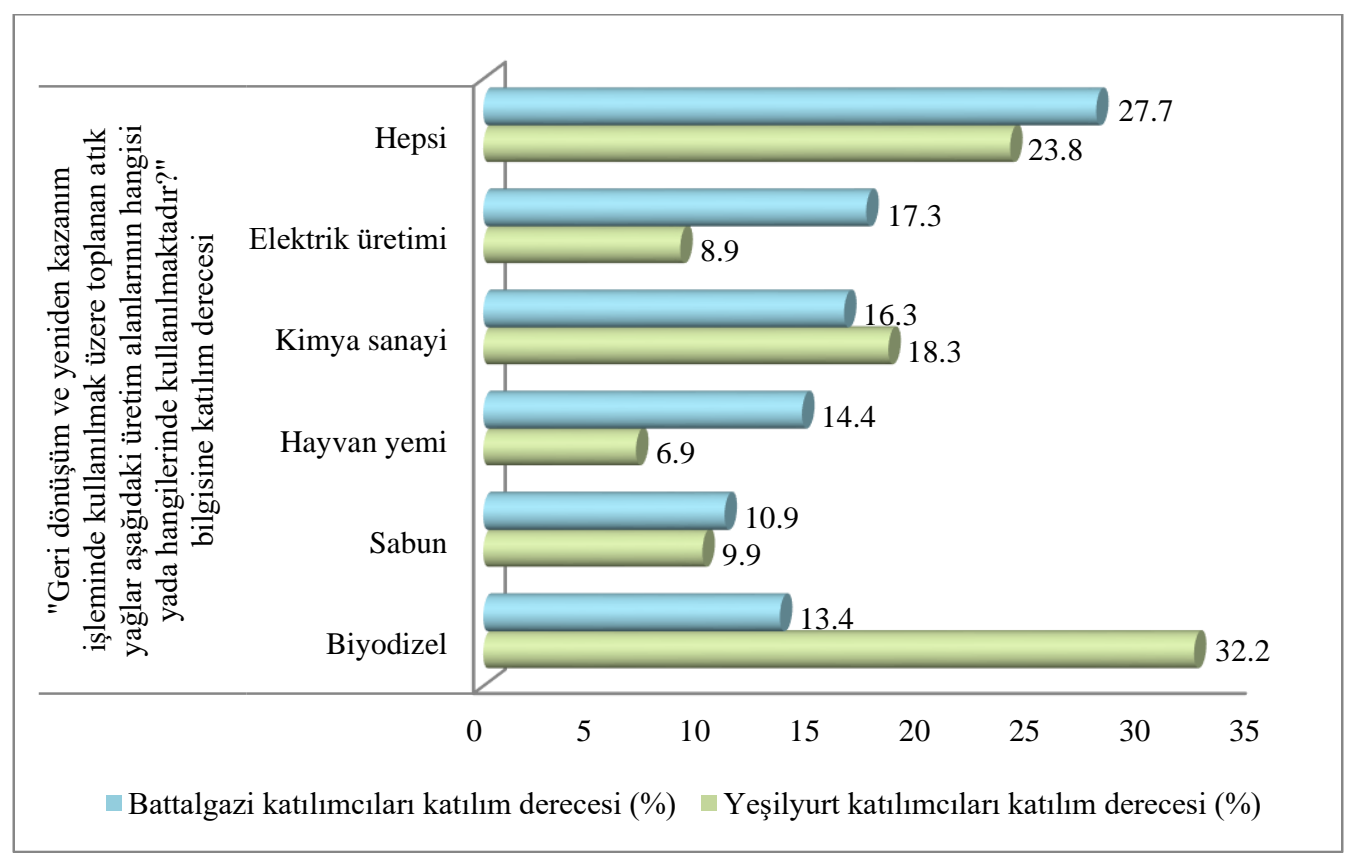

Şekil 14: Katıımcıların bitkisel atık yağların hangi üretim alanlarında ham madde olarak kullanıldığını bilme oranı

Bir veya birden fazla seçimin yapılabileceği bu soruya Battalgazi katılımcıları, ilkokul mezunlarından 5 birey Biyodizel, 5 birey Sabun, 6 birey Hayvan yemi, 5 birey Kimya sanayi, 8 birey Elektrik, 6 birey Hepsi; ortaokul mezunlarından 3 birey Biyodizel, 4 birey Sabun, 5 birey Hayvan yemi, 6 birey Kimya sanayi, 7 birey Elektrik, 6 birey Hepsi; lise mezunlarından 11 birey Biyodizel, 5 birey Sabun, 6 birey Hayvan yemi, 12 birey Kimya sanayi, 10 birey Elektrik, 15 birey Hepsi; önlisans mezunlarından 2 birey Biyodizel, 1 birey Sabun, 5 birey Hayvan yemi, 4 birey Kimya 
sanayi, 2 birey Elektrik, 11 birey Hepsi; lisans mezunlarından 6 birey Biyodizel, 7 birey Sabun, 7 birey Hayvan yemi, 4 birey Kimya sanayi, 7 birey Elektrik, 15 birey Hepsi; lisans üstü mezunlarından 1 birey Kimya sanayi, 1 birey Elektrik, 3 birey Hepsi yanıtını vermiştir. Bir veya birden fazla seçimin yapılabileceği bu soruya Yeşilyurt katılımcıları, ilkokul mezunlarından 6 birey Biyodizel, 5 birey Sabun, 5 birey Hayvan yemi, 3 birey Kimya sanayi, 1 birey Elektrik, 9 birey Hepsi; ortaokul mezunlarından 6 birey Biyodizel, 2 birey Sabun, 3 birey Hayvan yemi, 6 birey Kimya sanayi, 2 birey Elektrik, 2 birey Hepsi; lise mezunlarından 23 birey Biyodizel, 5 birey Sabun, 3 birey Hayvan yemi, 13 birey Kimya sanayi, 3 birey Elektrik, 12 birey Hepsi; önlisans mezunlarından 10 birey Biyodizel, 1 birey Sabun, 4 birey Kimya sanayi, 2 birey Elektrik, 9 birey Hepsi; lisans mezunlarından 20 birey Biyodizel, 7 birey Sabun, 3 birey Hayvan yemi, 10 birey Kimya sanayi, 8 birey Elektrik, 14 birey Hepsi; lisans üstü mezunlarından 1 birey Elektrik, 2 birey Hepsi yanıtını vermiştir.

Bitkisel Kaynaklı Yağ Atıklarının Geri Dönüşümü bölümünde anket katılımcılarına son olarak "Bitkisel kaynaklı atık yağların dönüşümü ile elde edilebilen biyodizelin çevre dostu bir yakıt olduğunu biliyor musunuz?" sorusu yöneltilmiş ve yanıtların oranı Şekil 15'te verilmiştir. Battalgazi katılımcıları \%40 oranında, Yeşilyurt katılımcıları ise \%54.7 oranında Evet yanıtını vermiştir.

Battalgazi ilçesi kadın katılımcıları, bu soruya \%27.3 oranında Evet, \%21.3 oranında Hayır yanıtını vermiştir. Battalgazi ilçesi erkek katılımcıları ise, bu soruya \%28.7 oranında Evet, \%22.7 oranında Hayır yanıtını vermiştir. Yeşilyurt ilçesi kadın katılımcıları, bu soruya \%32 oranında Evet, \%16 oranında Hayır yanıtını vermiştir. Yeşilyurt ilçesi erkek katılımcıları ise, bu soruya \%42 oranında Evet, \%10 oranında Hayır yanıtını vermiştir. Katılımcıların eğitim durumlarına göre bu soruya Battalgazi ilçesi katılımcılarından, ilkokul mezunları \%7.3 oranında Evet, \%8.7 oranında Hayır; ortaokul mezunları \%7.3 oranında Evet, \%4.7 oranında Hayır; lise mezunları \%16 oranında Evet, \%16.7 oranında Hayır; önlisans mezunları \%8 oranında Evet, \%5.4 oranında Hayır; lisans mezunları \% 13.3 oranında Evet, \% 9.3 oranında Hayır; lisans üstü mezunları \%2 oranında Evet, \% 1.3 oranında Hayır yanıtını vermiştir. Katılımcıların eğitim durumlarına göre bu soruya Yeşilyurt ilçesi katılımcılarından, ilkokul mezunları \%10 oranında Evet, \%6.7 oranında Hayır; ortaokul mezunları \%4.7 oranında Evet, \%4 oranında Hayır; lise mezunları \%24 oranında Evet, \%8.7 oranında Hayır; önlisans mezunları \%12 oranında Evet, \%1.3 oranında Hayır; lisans mezunları \%22.6 oranında Evet, \%4 oranında Hayır; lisans üstü mezunları \%0.7 oranında Evet, \%1.3 oranında Hayır yanıtını vermiştir.

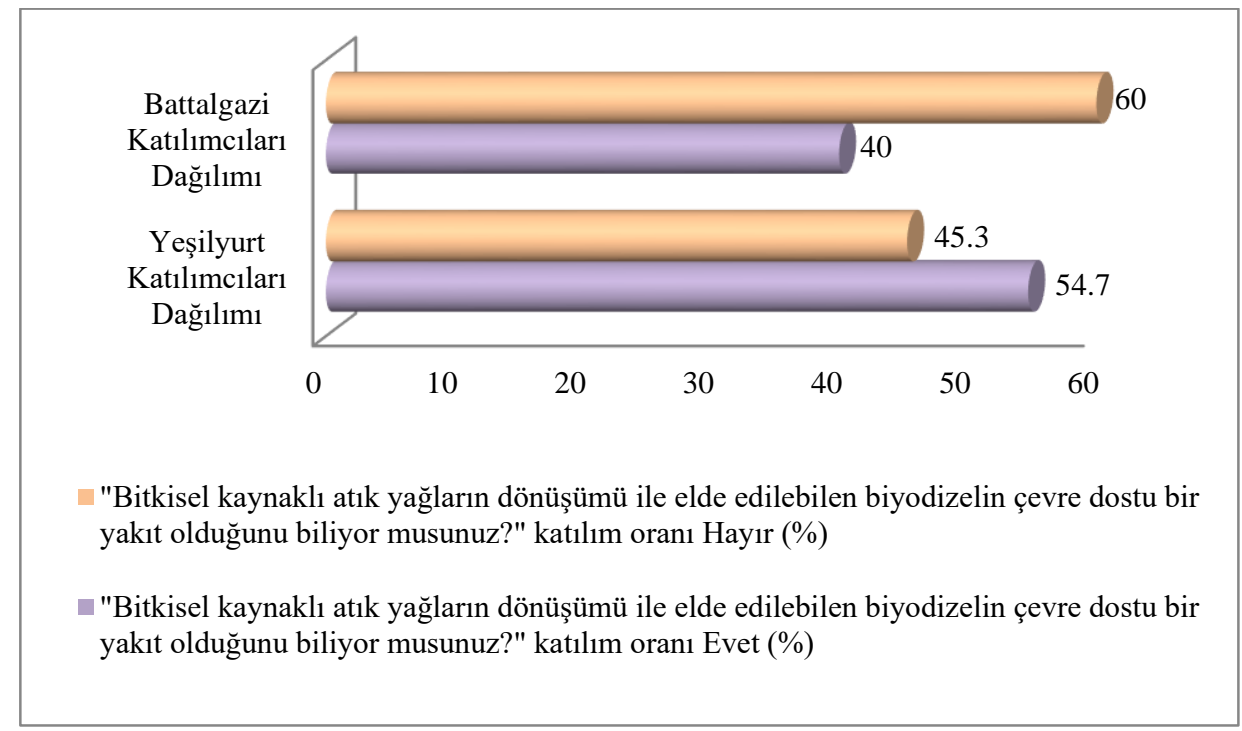

Şekil 15: Katıımcıların "Bitkisel kaynaklı atık yağların dönüşümü ile elde edilebilen biyodizelin çevre dostu bir yakıt olduğunu biliyor musunuz?" sorusuna yanıtlarının oranı

Atık bitkisel yağların, çevre kirliliğine etkilerini azaltabilmede halkın farkındalığı sürdürülebilirlik için önemlidir. Bitkisel yağlar kullanıldıktan sonra biyodizel, sabun, hayvan yemi, kimya sanayi ve elektrik üretimi alanlarında ham madde olarak kullanılabilir. Anket uygulamasına ilkokul'dan lisans üstü'ne her eğitim seviyesinden birey katılmıştır. Katılımcılara, bitkisel atık yağların çevreye etkileri ve geri dönüşümü ile ilgili spesifik sorular yöneltilmiş olmasına rağmen, yanıtların oranlarına göre halkın bu spesifik konulara hakim olduğu anlaşılmıştır.

\section{Sonuç ve Öneriler}

Küresel enerji talebinde artış, yenilenemez fosil yakıtların tüketimi, küresel 1sınma, çevre kirliliği gibi faktörler geri dönüşüm ile ilgili araştırmalara yön vermiştir. Geri dönüşüm ile atık veya atık sular çevreye zarar vermeden faydalı ham maddeler olarak kullanılabilir. Bu kapsama, atık bitkisel yağlarda dahildir. 
Bitkisel yağların yemeklik kullanımı sonrasında elde edilen atık yağlar, bilinçli olarak geri dönüşüme kazandırılmazsa çok önemli çevresel sorunlara sebebiyet verebilir. Atık bitkisel yağların çevreye etkileri ve geri dönüşümü hususunda halkın farkındalığı sayesinde, atık yağlar biyodizel, sabun, hayvan yemi, elektrik üretimi, kimya sanayi alanlarında ham madde olarak kullanılmak üzere geri dönüşüme kazandırılabilir. Böylece, bitkisel atık yağlar çevre kirliliğine sebep olmadan değerlendirilebilir.

$\mathrm{Bu}$ çalışmada, Malatya ili merkez ilçeleri olan Battalgazi ve Yeşilyurt'ta rastgele seçilmiş katılımcılara atık bitkisel yağların çevreye etkileri ve geri dönüşümü ile ilgili bilgi düzeylerine yönelik farkındalıklarını değerlendirmek amacıyla anket uygulanmış ve sonuçları irdelenmiştir. Sonuçlar genel olarak değerlendirildiğinde:

- Anket uygulamasına katılan ilkokul'dan lisans üstü'ne her eğitim seviyesinde bireye, bitkisel atık yağların çevreye etkileri ve geri dönüşümü ile ilgili spesifik sorular yöneltilmiş olmasına rağmen, değerlendirmelere göre Battalgazi ve Yeşilyurt ilçesi halkının bu spesifik konulara hakim olduğu,

- Bitkisel kaynaklı yağ atıklarının çevreye etkileri ve Bitkisel kaynaklı yağ atıklarının geri dönüşümü bölümlerinde, katılımcılara yöneltilmiş sorulara ve beyan edilmiş yanıtlara göre her iki ilçede de farkındalığın yüksek olduğu saptanmıştır. Bu bölümlerdeki spesifik soruların yanıtlarına göre, her iki ilçede yaşayan halk spesifik sorulara \% 75 ve üstü oranlarda Kesinlikle katılıyorum ya da Katılıyorum yanıtını vermiş dolayısıyla, bu oranla halkın farkındalığının yüksek olduğu kanısına varılmıştır. Her iki ilçe arasında değerlendirme yapıldığında, Yeşilyurt ilçesinde Battalgazi ilçesine göre daha fazla farkındalık olduğu,

- Her iki ilçede de çevre koruma bilincinin yüksek olduğu,

- Ailedeki birey sayısı ile kullanım sonrası oluşan atık yağ miktarı arasında doğru orantı olduğu,

- Her iki ilçe katılımcılarının, ortalama \% 50 oranlarında haftalık 1-2 defa kızartma yapmış oldukları, kızartmalık yağ kullanımında ağırlıklı olarak zeytinyağı ve ayçiçek yağını tercih ettikleri,

- Battalgazi ve Yeşilyurt belediyelerinin, okullarda çevre ve insan sağlığının önemini anlatan animasyon, çizgi fillm ve çeşitli sinevizyon gösterimleriyle desteklenen eğitim çalışmaları yapmış olmasının faydalı olduğu,

- Atık bitkisel yağların çevreye etkileri konusunda bilgi sahibi olmayan katılımcılara, anket uygulaması sonrasında konu ile ilgili bilgilendirmeler yapılarak benzer çalışmaların diğer illerde uygulanması gerektiği,

belirlenmiştir.

Gelecek nesillere, yaşanılabilir bir çevre bırakabilmek için toplum olarak herkes üzerine düşen gerekli özen ve hassasiyeti göstermelidir. Bu nedenle, çevre duyarlılığı hususunda toplumun bilinçlendirilmesi gerekmektedir. Bitkisel atık yağların çevreye etkileri ve geri dönüşümü hususunda, ülke genelinde bilgilendirme faaliyetleri yapılmalıdır. Bu kapsamda üniversiteler, kamu, özel ve sivil toplum kuruluşları koordineli olarak faaliyet göstermelidir.

\section{Teşekkür}

Anketin uygulanmasına katkı sağlayan kuzenim Ahmet Faruk OTCU'ya teşekkür ederim.

\section{Kaynaklar}

Brito A., Borges M.E., Otero N., (2007), Zeolite Y as a heterogeneous catalyst in biodiesel fuel production from used vegetable oil, Energy Fuels, 21(6), 3280-3283.

Christopher L.P., Kumar H., Zambare V.P., (2014), Enzymatic biodiesel: Challenges and opportunities, Applied Energy, 119, 497520.

Chung K.H., Chang D.R., Park B.G., (2008), Removal of free fatty acid in waste frying oil by esterification with methanol on zeolite catalysts, Bioresource Technology, 99(16), 7438-7443.

Endalew A.K., Kiros Y., Zanzi R., (2011), Inorganic heterogeneous catalysts for biodiesel production from vegetable oils, Biomass and Bioenergy, 35, 3787-3809.

Gui M.M., Lee K.T., Bhatia S., (2008), Feasibility of edible oil vs. non-edible oil vs. waste edible oil as biodiesel feedstock, Energy, $33,1646-1653$.

Körbıtz W., (1999), Biodiesel production in Europe and North America, an encouraging prospect, Renewable Energy, 16, $1078-1083$.

Kulkarni M.G., Dalai A.K., (2006), Waste cooking oil - An economical source for biodiesel: A review, Industrial \& Engineering Chemistry Research, 45(9), 2901-2913.

Lee A.F., Bennett J.A., Manayil J.C., Wilson K., (2014), Heterogeneous catalysis for sustainable biodiesel production via esterification and transesterification, Chemical Society Reviews, 43, 7887-7916.

Li J., Wang X., Zhu W., Cao F., (2009), $\mathrm{Zn}_{1.2} \mathrm{H}_{0.6} \mathrm{PW}_{12} \mathrm{O}_{40}$ nanotubes with double acid sites as heterogeneous catalysts for the production of biodiesel from waste cooking oil, ChemSusChem, 2, 177-183.

Li L., Quan K., Xu J., Liu F., Liu S., Yu S., Xie C., Zhang B., Ge X., (2013), Liquid hydrocarbon fuels from catalytic cracking of waste cooking oils using basic mesoporous molecular sieves $\mathrm{K}_{2} \mathrm{O} / \mathrm{Ba}-\mathrm{MCM}-41$ as catalysts, ACS Sustainable Chemistry \& Engineering, $1(11), 1412-1416$.

Ong L.K., Kurniawan A., Suwandi A.C., Lin C.X., Zhao X.S., Ismadji S., (2013), Transesterification of leather tanning waste to biodiesel at supercritical condition: Kinetics and thermodynamics studies, The Journal of Supercritical Fluids, 75, 11-20.

OSWER Innovations Pilot, (2004), Reducing production costs and nitrogen oxide (NO $)_{x}$ emissions from biodiesel, Environmental Protection Agency (EPA), 500-F--04-022. https://nepis.epa.gov/Exe/ZyPDF.cgi/P1009SHT.PDF?Dockey=P1009SHT.PDF, [Erişim 30 Haziran 2019]. 
Parawira W., (2009), Biotechnological production of biodiesel fuel using biocatalysed transesterification: A review, Critical Reviews in Biotechnology, 29(2), 82-93.

Pinto A.C., Guarieiro L.L.N., Rezende M.J.C., Ribeiro N.M., Torres E.A., Lopes W.A., Pereira P.A.P., Andrade J.B., (2005), Biodiesel: An overview, Journal of the Brazilian Chemical Society, 16(6B), 1313-1330.

Shibasaki-Kitakawa N., Tsuji T., Kubo M., Yonemoto T., (2011), Biodiesel production from waste cooking oil using anion-exchange resin as both catalyst and adsorbent, BioEnergy Research, 4(4), 287-293.

Singh S.P., Singh D., (2010), Biodiesel production through the use of different sources and characterization of oils and their esters as the substitute of diesel: A review, Renewable and Sustainable Energy Reviews, 14, 200-216.

URL-1, (2019), Bitkisel atık yağların geri kazanımı projesi, http://www.cankaya.bel.tr/pages/187/Bitkisel-Atik-Yaglarin-GeriKazanimi-Projesi, [Erişim 1 Temmuz 2019].

URL-2, (2019), Endüstriyel kirlenme, https://acikders.ankara.edu.tr/pluginfile.php/15357/mod_resource/content/0/5.\%20hafta.pdf, [Erișim 30 Haziran 2019].

URL-3, (2019), Bitkisel atık yağlar, http://cevreonline.com/bitkisel-atik-yaglar/, [Erişim 30 Haziran 2019].

URL-4, (2019), Battalgazi Belediyesi, http://www.battalgazi.bel.tr/, [Erişim 1 Kasım 2019].

URL-5, (2019), Yeşilyurt Belediyesi, http://www.yesilyurt.bel.tr/, [Erişim 1 Kasım 2019].

URL-6, (2019), Demografi, https://www.endeksa.com/tr/, [Erişim 1 Kasım 2019]. 